\title{
17 Fungi and Their Enzymes for Pitch Control in the Pulp and Paper Industry
}

\author{
Ana Gutiérrez ${ }^{1}$, José C. Del Río ${ }^{1}$, Ángel T. Martínez ${ }^{2}$
}

\section{CONTENTS}

I. Introduction.

357

II. Pitch Problems in Pulp and Paper

Manufacturing ............................ 357

A. Resin in Plant Raw Materials.............. 358

B. Resin in Pulp and Paper .................. 359

III. From "Natural" to "Controlled" Seasoning

of Wood .................................... 360

A. Sapstain Fungi........................ 361

B. White-Rot Fungi..................... 362

IV. Pitch Biocontrol with Fungal Enzymes........ 363

A. Hydrolytic Enzymes...................... 363

B. Oxidative Enzymes ..................... 366

V. Summary and Conclusions ................ 372

References ............................ 373

\section{Introduction}

Traditionally, the use of biotechnology has been mainly confined to fermentation processes in the food and beverage industry and in the pharmaceutical sector. Over the past decades, however, biotechnology has gained ground from chemical processes in the manufacturing of a variety of industrial products, including pulp and paper (Skals et al. 2008). During recent years, the number of applications of enzymes in pulp and paper manufacturing has steadily grown, and several have reached or are approaching commercial use. These include enzyme-aided bleaching with xylanases, direct delignification with oxidative enzymes, refining with cellulases, pitch reduction with lipases, freeness enhancement with cellulases and hemicellulases as well as enzymatic slime control (Bajpai 1999, 2006). In addition to enzymes, microbial treatments have the potential

\footnotetext{
${ }^{1}$ Instituto de Recursos Naturales y Agrobiología de Sevilla, CSIC, PO Box 1052, 41080 Seville, Spain; e-mail: anagu@irnase.csic.es; delrio@irnase.csic.es

${ }^{2}$ Centro de Investigaciones Biológicas, CSIC, Ramiro de Maeztu 9, 28040 Madrid, Spain; e-mail: atmartinez@cib.csic.es
}

to increase pulping efficiency, reduce pitch problems, and enhance process water re-use.

In the present chapter, we focus on an important aspect of pulp and paper manufacturing, namely pitch control, which is the first example where biotechnology provided successful solutions in this industrial sector. To determine the practical potential of a biological treatment for pitch control, it is imperative to understand the heterogeneity of lipophilic extractives in wood and pulp, to determine which classes of lipids are important in pitch deposition, and to assess the effectiveness of biological agents in reducing and removing many in all troublesome lipid classes. With this purpose, an overview of the pitch problems in the pulp and paper industry is first provided, followed by a description of the state of the art and the current research on biotechnological solutions to pitch problems, including the use of fungal strains for the pretreatment of wood chips prior to pulping and fungal enzymes for the direct treatment of pulps. Finally, some concluding remarks and future trends in this field are included.

\section{Pitch Problems in Pulp and Paper Manufacturing}

Lipophilic wood extractives, i.e. the non-polar extractable fraction from wood often referred to as wood resin (Fig. 17.1A), cause so-called pitch deposits during pulp and paper manufacturing processes (Fig. 17.1B). Pitch deposition is a serious problem in the pulp and paper industry since it is responsible for reduced production levels, higher equipment maintenance costs, higher operating costs, and an increased incidence of defects in the finished products, which reduces quality and benefits (Back and Allen 2000). 

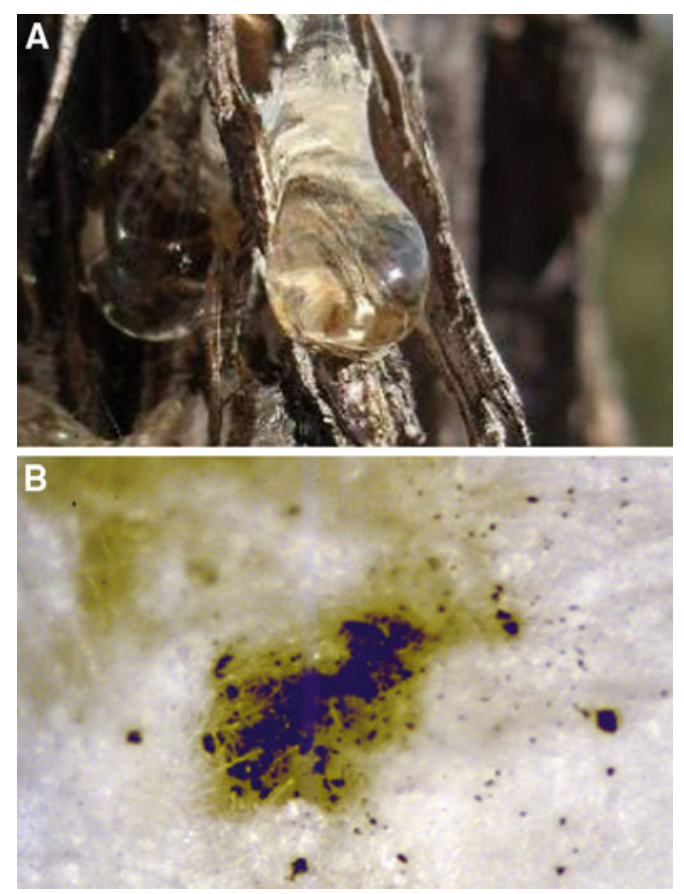

Fig. 17.1. Resin exudate on a conifer tree (A) and pitch deposit in a TCF pulp (B); courtesy of M.J. Ortega and J. Romero, respectively

Furthermore, process effluents containing wood extractives may also be toxic and harmful to the environment (Leach and Thakore 1976; Liss et al. 1997).

\section{A. Resin in Plant Raw Materials}

Lipophilic extractives comprise a variety of different compounds including alkanes, fatty alcohols, fatty acids, resin acids, sterols, other terpenoids, conjugated sterols (as esters and glycosides), triglycerides, and waxes (Fig. 17.2). The content and composition of resin vary considerably between the different angiosperm and gymnosperm species (Fig. 17.3) and even between different parts of the same plant. Some differences are caused by the growing conditions, the age of the tree, and other genetic and environmental factors.

The resin components of softwoods (gymnosperms) commonly used in the pulp and paper industry, such as Scots pine (Pinus sylvestris) and Norway spruce (Picea abies), have been extensively studied (Ekman and Holmbom 2000). Triglycerides, resin acids, and fatty acids represent a high percentage of Scots pine extractives.
Norway spruce contains similarly high amounts of triglycerides, resin acids, and steroids. All these lipophilic compounds have been traditionally associated with pitch problems in the papermaking process (Back and Allen 2000; Ekman and Holmbom 2000).

Among hardwood trees (woody angiosperms), silver birch (Betula pendula) and trembling aspen (Populus tremuloides) have been traditionally used for paper pulp production and, therefore, their wood resin have been thoroughly studied (Ekman and Holmbom 2000). A significantly higher proportion of sterols and other unsaponifiable lipids are reported in birch and aspen compared to softwoods, although triglycerides predominate in both species. Resin acids present in all kinds of softwood are not found in hardwoods. Sterol esters and waxes (Chen et al. 1995) and triterpenols and saturated fatty acids (Bergelin et al. 2005) are reported to be at the origin of pitch deposits in aspen and birch, respectively. New pieces of information on the composition of lipophilic extractives have come from eucalypt wood (Eucalyptus globulus and related species), during the past ten years due to the increasing use of this fast-growing hardwood tree by the paper pulp industry. Free and conjugated sterols (in the form of fatty-acid esters and glycosides) are the main lipophilic components of eucalypt wood, together with other steroids and free fatty acids (Freire et al. 2002; Gutiérrez et al. 1999a, 2001; Rencoret et al. 2007), being also responsible for pitch deposition (del Río et al. 1998, 1999, 2000; Freire et al. 2005; Gutiérrez et al. 2001b, c; Silvestre et al. 1999).

The chemical composition of lipophilic extractives from non-woody species used by the pulp and paper industry has not been as extensively studied as that of woody species, although knowledge on straw-like materials has accumulated during recent years (del Río and Gutiérrez 2006; Gutiérrez and del Río 2003a, b; Morrison and Akin 2001; Sun and Sun 2001). Fatty acids, free and esterified sterols, triglycerides, and waxes are the predominant lipophilic compounds in wheat-straw, which is an important raw material for pulp and paper manufacturing in China because of the shortage of forest resources and the extensive supply of wheat-straw (Sun and Sun 2001). Alkanes, fatty alcohols and fatty acids, aldehydes, sterols, and waxes are the major lipid compounds identified in non-woody plants such as flax, hemp, kenaf, sisal, and abaca, which are used in developed countries for the production of high-quality pulps for specialty papers. In particular, fatty alcohols, alkanes, and sterols are among the compounds responsible for pitch deposits formed during pulping of non-woody plants (Gutiérrez and del Río 2005). 
Fig. 17.2. Chemical structures of selected compounds representing the main classes of lipophilic extractives found in woody and non-woody plants, including alkanes (octadecane), fatty alcohols (1-hexadecanol), fatty acids (palmitic acid), resin acids (abietic acid), sterols (sitosterol), triterpenols (betulinol), sterol esters (sitosteryl linoleate), sterol glycosides (sitosteryl $3 \beta$-D-glucopyranoside), triglycerides (trilinolein), and waxes (octacosyl hexadecanoate)

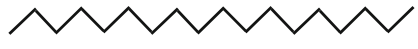

octadecane<smiles>CCCCCCCCCCCCCCCCCCC(=O)O</smiles>
palmitic acid<smiles>CCCCCCCCCCCCCCCCO</smiles><smiles></smiles><smiles>CCCCC/C=C/C/C=C\CCCCCCCC(=O)OC1CCC2(C)C(=CCC3C2CCC2(C)C(C(C)CCC(CC)C(C)C)CCC32)C1</smiles>
sitosteryl linoleate

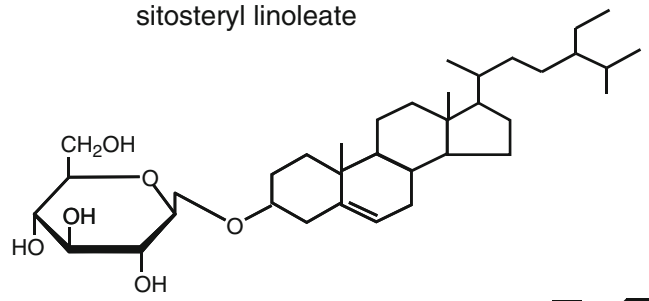

sitosteryl 3 $\beta$-D-glucopyranoside

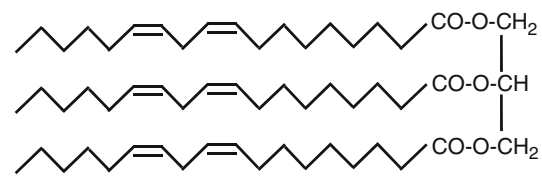
trilinolein<smiles>CCCCCCCCCCCCCCCCCCCCCCCCCCCOC(=O)CCCCCCCCCCCCCCC</smiles>

\section{B. Resin in Pulp and Paper}

The lipophilic extractives present in the raw materials can cause pitch problems along the entire pulp and paper manufacturing processes (pulping, bleaching, paper machine processing). The nature and severity of pitch problems depend not only on the raw materials used, but also on the industrial processes of pulping and bleaching applied at the mill. In this way, mechanical pulping often applied to softwoods for manufacturing newspaper and similar pulps, slightly affects the composition of extractives since no chemicals acting on lignin are added. Therefore, the corresponding pulp extractives show a composition similar to that found in natural softwood. In contrast, chemical pulping, including kraft cooking that provides over $50 \%$ of the total paper pulp, modifies the extractives composition to different extents depending on the raw material. In this way, an important fraction of pitch-forming compounds in softwoods is removed during kraft cooking, since it consists of triglycerides that are completely saponified under the alkaline 


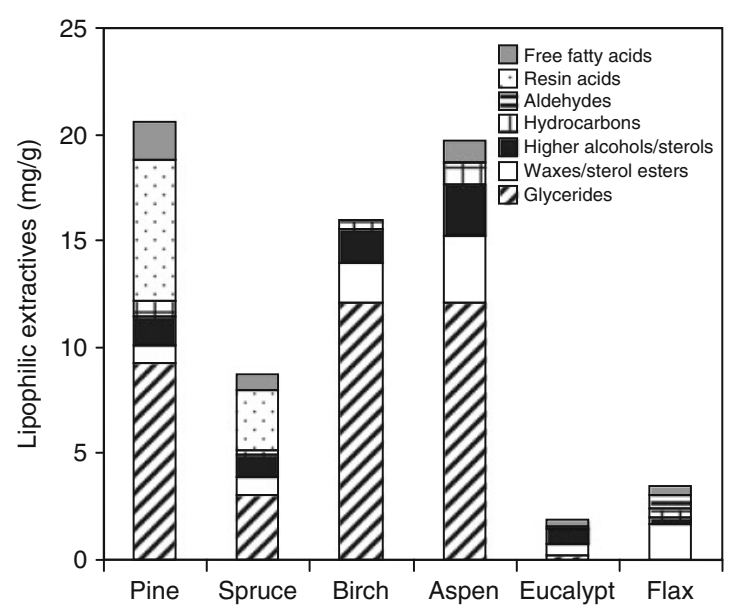

Fig. 17.3. Abundances of main classes of lipophilic extractives in several softwoods (pine, spruce), hardwoods (birch, aspen, eucalypt) and a non-woody plant (flax). Data from Fengel and Wegener (1984), Gutiérrez et al. (1999a) and Gutiérrez and del Río (2003a, b)

conditions used and the fatty and resin acids are dissolved (Fengel and Wegener 1984). The sterol and triterpenol esters, especially abundant in many hardwoods including eucalypt and birch, are saponified more slowly than the glycerol esters (Bergelin and Holmbom 2003; Gutiérrez et al. 2001b). The remaining free and esterified sterols and triterpenols do not form soluble soaps as free acids do and, therefore, have a tendency to deposit.

The wood extractives remaining in the unbleached pulp are carried over to the bleach plant, where they react with the bleaching agents used (Jansson et al. 1995). Pulp bleaching technology radically changed in the 1990s, and the previously used chlorine was replaced and new bleaching sequences were introduced. The use of totally chlorinefree (TCF) bleaching in place of elementary chlorine-free (ECF) bleaching has increased the severity of pitch problems due to the lower reactivity with pulp lipids (Gutiérrez et al. 2001b). This applies to most unsaturated steroids and triterpenoids as well as fatty acids, which are strongly modified by chlorine dioxide $\left(\mathrm{ClO}_{2}\right)$ used in ECF bleaching but remain practically unaltered by oxygen and hydrogen peroxide used in TCF bleaching sequences (Bergelin and Holmbom 2003; Freire et al. 2005, 2006; Gutiérrez et al. 2001b). Pitch colloidal particles "surviving" the action of bleaching chemicals, can coalesce and deposit in the pulp or the equipment, resulting in low quality pulp and causing the shutdown of pulp mill operations. The residual resin in the pulp is at the origin of pitch problems in the paper mill, including spots and holes in the paper, sheet breaks, and technical shutdowns of the paper machine
(Allen 2000a). Moreover, in the paper mills as well as in the pulp mill, the degree of system closure can have a considerable impact on the propensity to pitch problems. Thus, when white waters recirculate, there is a tendency for the dissolved and dispersed resins to increase in concentration which, in turn, increase the tendency for the formation of certain kinds of pitch (Allen 2000b).

Because the nature of pitch problems can be very different depending on the raw material and the process used, different physicochemical methods to control pitch in pulp and paper mills are used (Allen 2000a, b). These include adsorption or dispersion of the pitch particles with chemicals in the pulping and papermaking processes by adding alum, talc, ionic or non-ionic dispersants, cationic polymers, and other types of additives. In addition to chemical solutions, biological methods to control pitch problems have also been developed, as described below.

\section{From "Natural" to "Controlled" Seasoning of Wood}

Traditional methods to control pitch problems include deliberate storage of logs and/or wood chips in the woodyard before pulping (natural "seasoning"). The outside storage of pulpwood was introduced in the 1920s for whole logs and in the early 1950s for wood chips (smaller pieces of chopped wood) (Farrell et al. 1997). This method was the direct consequence of the need to stockpile wood as inventory to mill and to season wood, which resulted in decreased resin deposition. During wood storage, the content of extractives decreases since some of them are subject of hydrolytic or oxidative transformations by plant enzymes as well as by the action of wood-colonizing microorganisms. The reactions of wood resin components during storage have been studied for several pulpwood species including spruce, pine, birch, aspen, and eucalypt (Ekman 2000; Gutiérrez et al. 1998; Silvério et al. 2008). However, prolonged storage causes a decrease in the pulp brightness and yield due to the uncontrolled action of microorganisms. Therefore, the industrial practice today does not include overlong log or chip storage times. In addition, polymerization of unsaturated wood resin components are also reported to occur during seasoning 
and studies with model compounds have been performed (Ekman 2000; Sitholé et al. 2009). As an alternative, the use of special fungi to accelerate and control the seasoning of wood has been considered. The ability to colonize lignified plant materials is a characteristic of wood-decay fungi, including white-rot, brown-rot, soft-rot, and sapstain species (Martínez et al. 2005). Among these eco-physiological groups, selected sapstain and white-rot fungi have particularly been considered for the control of pitch, as explained below. In addition, wood treatment with bacteria to remove lipophilic extractives has also been suggested and studied in the laboratory (Burnes et al. 2000; Kallioinen et al. 2003).

\section{A. Sapstain Fungi}

A small number of ascomycetes, so-called staining fungi, colonize wood through parenchymatic rays and resin canals. They cause the discoloration of sapwood tissues, due to the presence of melaninlike pigments in the fungal hyphae (Zimmerman et al. 1995), but only a limited degradation that mainly affects extractives and water-soluble components (Martínez et al. 2005). Since most lipophilic compounds involved in the formation of pitch deposits are concentrated in wood rays and resin canals, the sapstain fungi were the first candidates for the biological control of pitch (Brush et al. 1994; Farrell et al. 1993). Sapstain, also called blue stain, is caused by different pioneer colonizers, such as Ophiostoma, Ceratocystis, Leptographium or Sphaeropsis species, which utilize fatty acids, triglycerides, simple carbohydrates, and other components of the sapwood (Farrell et al. 1993). In addition, these fungi can rapidly colonize non-sterile wood chips. Research on the biotechnological application of sapstain fungi for wood depitching has mainly focused on Ophiostoma piliferum strains, a dark-colored ascomycete (Fig. 17.4A) widely distributed in forests and in chip piles. These research efforts led to the commercialization of an albino strain (Cartapip 97) of this fungus (Fig. 17.4B) for pitch reduction in wood chip piles without causing any staining effect. This and other colorless strains were obtained by classic mating approaches (followed by single ascospore isolation) and neither mutagenesis nor genetic engineering methods were applied. As in the case of other sapstain
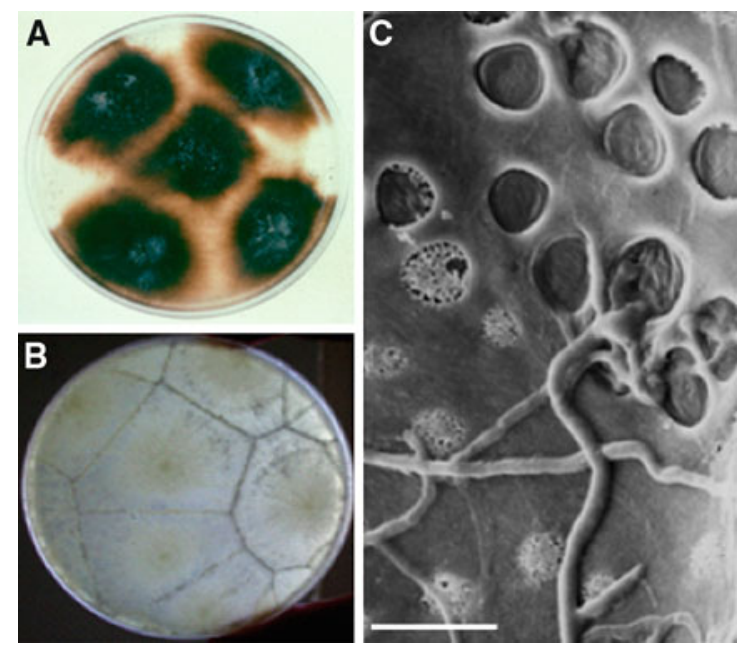

Fig. 17.4. Wild (A) and albino (B) Ophiostoma piliferum strains, and typical growth of the albino fungal strain through wood vessels as revealed by scanning electron microscopy (C; bar $10 \mathrm{~m}$ ); courtesy of R. Farrell

fungi, their growth mainly proceeds through wood vessels and rays (Fig. 17.4C), removing the extractives that accumulate in these structural elements.

Cartapip 97 was originally marketed by Sandoz Chemicals/ Clariant Corporation and has been used by the pulp and paper industry for the past 15 years. A $90 \%$ decrease of triglycerides causing pitch problems in the manufacture of mechanical and acidic sulfite pulps was reported after Cartapip treatment of pine wood (Farrell et al. 1993). The capabilities of some Ophiostoma species and other sapstain fungi in removing different classes of lipophilic extractives were assessed for both softwoods (Table 17.1) and hardwoods (Table 17.2). Among others, the effectiveness of these fungi to degrade triglycerides and free fatty acids was demonstrated in several independent studies using different types of wood (Breuil et al. 1998; Brush et al. 1994; Dorado et al. 2000a; Gutiérrez et al. 1999b; Josefsson et al. 2006; Martínez-Íñigo et al. 1999; Rocheleau et al. 1999). A higher degradation rate was observed for Scots pine than for Norway spruce extractives, which was attributed to differences in the degradation of triglycerides (Josefsson et al. 2006). Some studies reported a low efficiency in the removal of sterol esters (Chen et al. 1994; Josefsson et al. 2006) whereas other reports showed a significant conversion of these compounds by sapstain fungi (Gutiérrez et al. 1999b; Martínez-Íñigo et al. 1999). However, the Cartapip strain and related fungi seem to be unable to efficiently remove free sterols from hardwoods and resin acids from softwoods (Chen et al. 1994; Dorado et al. 2000a; Gutiérrez et al. 1999b; Martínez-Íñigo et al. 1999), even though, a significant decrease in free sterols (up to 60\%) was reported by Su et al. (2004) to be caused by some newly screened fungal strains. 
Table 17.1. Degradation of main lipid classes in Pinus sylvestris sapwood and heartwood during the growth of two whiterot (Bjerkandera sp. and Funalia trogii) and two sapstain fungi (Ophiostoma ainoae and Ceratocystis allantospora) compared to the lipid content of a control wood (from Martínez-Iñigo et al. 1999)

\begin{tabular}{|c|c|c|c|c|c|}
\hline & \multirow[b]{2}{*}{ Control (mg/g) } & \multicolumn{4}{|c|}{ Lipid degradation (\%) } \\
\hline & & Bjerkandera sp. & F. troggi & O. ainoae & C. allantospora \\
\hline \multicolumn{6}{|l|}{ Sapwood } \\
\hline Fatty acids & 3.96 & 97 & 95 & 78 & 88 \\
\hline Resin acids & 8.92 & 90 & 81 & 0 & 24 \\
\hline Sitosterol & 0.16 & 69 & 50 & $0^{\mathrm{a}}$ & $0^{\mathrm{c}}$ \\
\hline Waxes & 1.60 & 100 & 100 & 93 & 94 \\
\hline Sterol esters & 1.20 & 100 & 100 & 100 & 79 \\
\hline Triglycerides & 7.30 & 100 & 100 & 100 & 100 \\
\hline \multicolumn{6}{|l|}{ Heartwood } \\
\hline Fatty acids & 2.15 & 87 & 38 & 26 & 45 \\
\hline Resin acids & 31.09 & 50 & 0 & 0 & 19 \\
\hline Sitosterol & 0.27 & 18 & 41 & $0^{\mathrm{b}}$ & $0^{\mathrm{d}}$ \\
\hline Waxes & 0.43 & 74 & 44 & 67 & 12 \\
\hline Sterol esters & 0.48 & 62 & 58 & 58 & 17 \\
\hline Triglycerides & 1.02 & 80 & 100 & 100 & 60 \\
\hline
\end{tabular}

${ }^{\mathrm{a}}$ The amount was increased by $1.20 \mathrm{mg} / \mathrm{g}$ wood

${ }^{\mathrm{b}}$ The amount was increased by $0.27 \mathrm{mg} / \mathrm{g}$ wood

${ }^{c}$ The amount was increased by $0.43 \mathrm{mg} / \mathrm{g}$ wood

${ }^{\mathrm{d}}$ The amount was increased by $0.19 \mathrm{mg} / \mathrm{g}$ wood

Table 17.2. Degradation of main lipid classes in Eucalyptus globulus wood by two white-rot (Phlebia radiata and Ceriporiopsis subvermispora) and two sapstain fungi (Ophiostoma valdivianum and O. piliferum) compared to the lipid content of a control wood (from Gutiérrez et al. 1999b)

\begin{tabular}{llllll}
\hline & & \multicolumn{4}{c}{ Lipid degradation (\%) } \\
\cline { 3 - 6 } & Control $(\mathrm{mg} / 100 \mathrm{~g})$ & P. radiata & C. subvermispora & O. valdivianum & O. piliferum \\
\hline Fatty acids & 17.2 & 90 & 97 & 8 & 47 \\
Sterols & 41.8 & 96 & 98 & -55 & -82 \\
Sterol esters & 33.6 & 100 & 100 & 45 & 78 \\
Triglycerides & 8.6 & 100 & 100 & 25 & 100 \\
\hline
\end{tabular}

In addition to pitch reduction, albino strains of $O$. piliferum and related species exert a biocontrol effect, preventing sapstain and other wood-rot fungi from growing on logs and wood chips (Held et al. 2003). This is due to the early appearance of $O$. piliferum as a wood-colonizer (pioneer species) and particularly applies to freshly cut wood, where not only the growth of late wood-colonizers (such as white-rot fungi) is repressed but also other sapstain species.

When Cartapip 97 is used as a biocontrol agent, it has the tradename Sylvanex. In 2008, the current owners of this technology, Parrac Ltd, improved the production and storage properties of this product, and they are now announcing the re-launching of Cartapip 97/Sylvanex 97 worldwide. Generally, this technology can refer to any albino strain of the genus Ophiostoma that is able to decrease the resin content resulting in the maintenance of brightness levels during transportation and storage of wood prior to pulping (Farrell 2007). An albino strain of Ceratocystis resinifera (named Kasper) has also been successfully tested for its ability to prevent discoloration of spruce sapwood (Morin et al. 2006).

\section{B. White-Rot Fungi}

White-rot fungi are the predominant degraders of lignin in nature (see Chapter 15). Some species preferentially degrade lignin and hemicelluloses over cellulose ("selective degraders"), whereas other species degrade all wood components simultaneously ("simultaneous degraders"). The ability of white-rot fungi to attack all major cell-wall components, including lignin, cellulose, 
and hemicelluloses has been well characterized (Blanchette 1995; Martínez et al. 2005). In addition, there are reports on the degradation of nonstructural components in woody tissues, such as wood extractives, by certain white-rot fungi (above all by species causing a selective degradation pattern).

The ability of white-rot fungi in removing lipophilic extractives was assessed both for softwoods and hardwoods (Tables 17.1 and 17.2, respectively). A comprehensive study reported on the fungal degradation of lipophilic extractives in sapwood and heartwood from Scots pine (Martínez-Íñigo et al. 1999). Triglycerides, fatty acids, sterol esters, and waxes in pine sapwood were almost completely removed by the white-rot fungi assayed (Table 17.1) and even sterols and resin acids were extensively degraded.

This work furthermore showed that the fungal degradation of heartwood extractives was not only limited by the degradative ability of the fungi, but also by the inhibitory effect exerted by the extractives themselves. Thus, the white-rot fungus Funalia trogii was strongly inhibited in heartwood, whereas a Bjerkandera sp. strain showed a high tolerance towards the toxic extractives and was the most efficient fungus in degrading extractives in Scots pine wood. Resin acids were already previously reported to cause the inhibition of wood-inhabiting fungi including white-rotters (Eberhardt et al. 1994). In another study, several white-rot fungi were tested for the removal and detoxification of extractives from Scots pine sapwood and the time course of extractives degradation by two preselected fungi, namely Bjerkandera sp. and Trametes versicolor, was monitored (Dorado et al. 2000b, 2001). The authors showed a fungal removal up to $90 \%$ of most lipophilic extractives which was accompanied by a 7- to 17-fold reduction in toxicity in the Microtox bioassay. Further studies were performed by these authors with $T$. versicolor to evaluate the effects of fungal treatment on spruce chips at laboratory scale, in terms of pulp and paper quality, thermo-mechanical pulping (TMP) parameters, and effluent toxicity (van Beek et al. 2007). Several studies on the removal of lipophilic extractives from E. globulus wood showed that a few white-rot fungi are able to remove up to $100 \%$ of the main extractives present in this wood.

These studies started with the screening of a large number of fungal species (21 ascomycetes, 33 basidiomycetes, 19 conidial fungi) including strains isolated from eucalypt wood (Martínez et al. 1999). Different patterns of lipophilic extractives degradation were analyzed (Gutiérrez et al. 1999b) and several white-rot basidiomycetes, including Phlebia and Ceriporiopsis species, were selected. They efficiently removed up to $100 \%$ both of free and esterified sterols (Table 17.2), which are particularly abundant in eucalypt wood. In contrast, several ascomycetous fungi including Cartapip decreased the sterol ester content but did not convert free sterols. The time-course of fungal removal of these compounds was followed to optimize the treatment time for selected fungal species, namely Phlebia radiata, Ceriporiopsis subvermispora, Bjerkandera adusta, and Pleurotus pulmonarius (Martínez-Iñigo et al. 2000). Kraft pulping and TCF bleaching of eucalypt wood chips treated with these four basidiomycetes and subsequent papermaking from the pulps obtained confirmed their potential for pitch biocontrol (Gutiérrez et al. 2000). Resin removal by wood chip treatment with white-rot fungi can have additional benefits in biomechanical and biochemical pulping due to the partial removal of lignin (Akhtar et al. 2000; Bajpai et al. 2001).

\section{Pitch Biocontrol with Fungal Enzymes}

Enzymes offer an environmentally benign and efficient alternative to chemical reagents in many industrial applications. Based on mechanism, the majority of the commercial enzymes are hydrolases (EC 3), while oxidoreductases (EC 1) account for a miniscule share (Xu 2005). This is in contrast to the widespread occurrence of oxidoreductases in nature. The gap between a vast natural repertoire of oxidoreductases and their limited commercial application creates the space for developing more oxidoreductase-based biocatalysts. Concerning pitch biocontrol, an enzymatic method using hydrolytic enzymes (lipases) to treat the pulp was the first example world-wide, in which an enzyme was successfully applied in the papermaking process. More recently, the high potential of certain oxidative enzymes for the removal of lipophilic compounds has been shown. Both established applications based on hydrolases and emerging applications based on oxidoreductases have a promising potential for pitch biocontrol in pulp and paper manufacturing and are therefore discussed below.

\section{A. Hydrolytic Enzymes}

Hydrolases are involved in the catalytic breakdown of glycosidic bonds in polysaccharides, the main constituents of plant biomass, and they are also active on peptide and ester bonds in proteins and lipids, respectively. Lipases (triacylglycerol acylhydrolases, EC 3.1.1.3) form a group of well known hydrolases, whose natural function is the hydrolysis of esters formed from glycerol and 
long-chain fatty acids. Their enzymology and structure is discussed in several review papers, some of which also provide overviews of the wide range of industrial applications of these enzymes (Bornscheuer et al. 2002; Hasan et al. 2006). Lipases commercialized by Novozymes A/S (Bagsvaerd, Denmark) under the trade name Resinase A2X were successfully applied at mill scale for the enzymatic control of pitch in mechanical softwood pulping in Japan in the early 1990s (Fujita et al. 1991, 1992; Hata et al. 1996; Matsukura et al. 1990). This enzymatic pitch control technology was initially developed in the 1980s by Jujo Paper Company (later Nippon Paper) in conjunction with the Japanese office of Novozymes and is still nowadays in use. In Europe, pilot-scale trials for pitch control in softwood sulfite pulp using Resinase also provided promising results (Fischer and Messner 1992a, b; Fischer et al. 1993), and more recently lipase has been successfully assayed at the mill-scale for stone-ground wood pulping of Northern spruce wood in Finland within the frame of a European Union (EU) project (www.irnase.csic.es/projects/ pitch). In addition to Resinase, other industrial lipases were also investigated for the enzymatic control of pitch (Gutiérrez et al. 2001a).

In December 1999, Nanping Paper Mill in China started the world's fastest newsprint paper machine at this time, whose main pulp supply came from ground-wood and TMP pulp, using local Chinese red pine (Pinus massoniana) as raw material. Due to the very high content of lipophilic extractives of this pine species, conventional pitch control programs were ineffective in preventing frequent pitch outbreaks on various parts of the paper machine during start-up. In March 2000, the mill conducted a trial with a formulated pitch control treatment, which contained a variety of Novozymes enzymes including lipase products. The efforts focused not only on the operation of the paper machine, but also on the pulp mills where the pitch has usually its highest concentration. Finally, the pitch outbreaks were successfully controlled by the use of enzyme cocktails and lipase-based treatments (Chen et al. 2001).

During the past years, knowledge on the structural basis of lipase activity has strongly increased, including information on the active site and the characteristic lid region that regulates the access of lipophilic substrates in Resinase and other lipases (Fig. 17.5A). In this context, Novozymes $\mathrm{A} / \mathrm{S}$, within the frame of an EU project (www.irnase.csic.es/projects/pitch), developed a

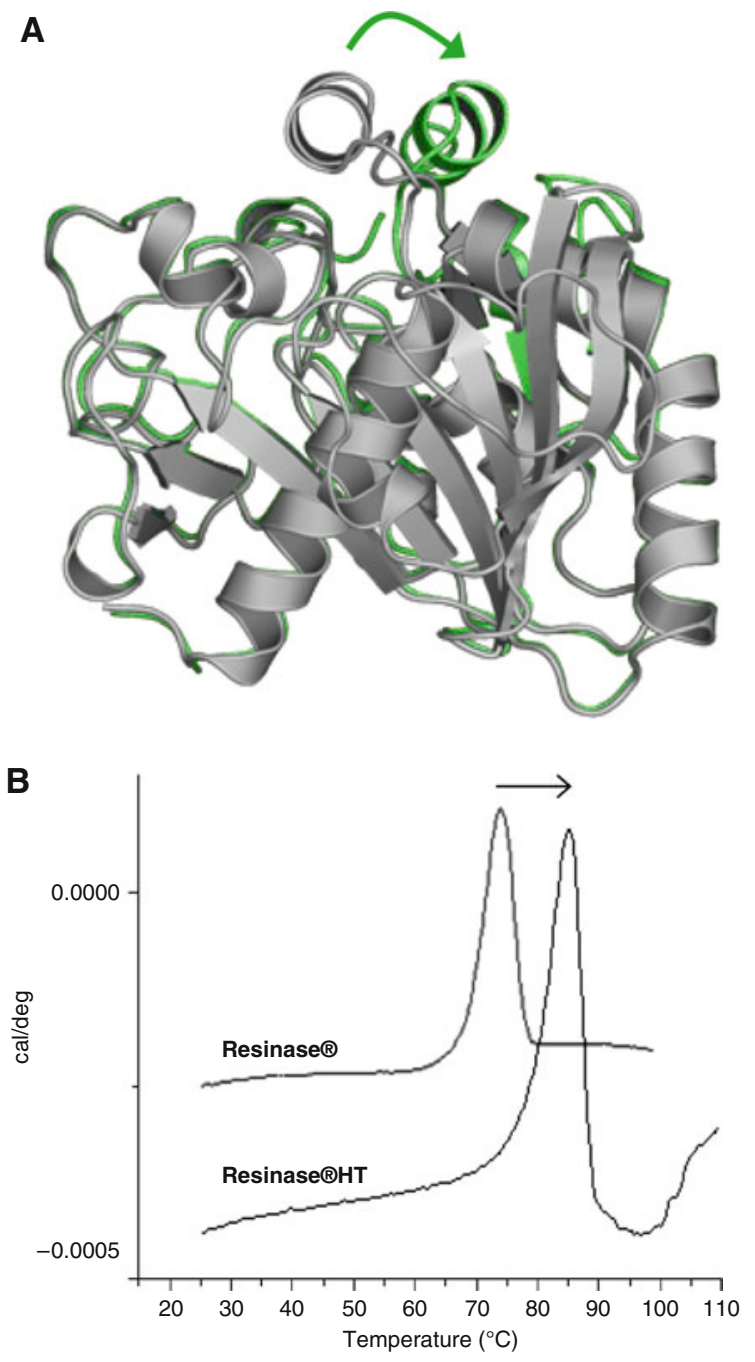

Fig. 17.5. Commercial lipase (Resinase from Novozymes A/S). A Scheme of the molecular structure showing the superimposition of the closed lid (gray) and open lid (green) conformations of the molecule to illustrate the opening of this mobile element (arrow) enabling the entrance of triglyceride substrates to the active site (the position of the different helices and $\beta$-sheets is also shown). B Differential scanning calorimetry showing the thermal stabilization (arrow) of the enzyme to obtain a thermostable variant (Resinase HT) by directed evolution (including random mutagenesis coupled to high throughput screening) within the framework of an EU project (www.irnase.csic.es/projects/pitch; courtesy of K. Borch, unpublished data)

Resinase variant that tolerates a $15{ }^{\circ} \mathrm{C}$ higher temperature than the wild-type enzyme (Fig. 17.5B). This was achieved by directed evolution techniques (i.e. random mutagenesis coupled to 
Table 17.3. Effect of enzymatic treatments of unbleached TMP with recombinant sterol esterase from M. albomyces (rSTE1) and lipase (Resinase A2X) on the lipophilic extractives of the TMP water compared with corresponding controls ( 1 and 2) without enzyme supplementation (from Kontkanen et al. 2006b)

\begin{tabular}{lllll}
\hline & \multicolumn{3}{c}{ Lipid content (mg/l) } \\
\cline { 2 - 5 } & Control 1 & rSTE1 & Control 2 & Resinase A2X \\
\hline Fatty acids & 6.1 & 11.7 & 6.2 & 18.7 \\
Resin acids & 7.7 & 7.1 & 8.5 & 8.9 \\
Sterols & 1.0 & 1.5 & 0.9 & 1.1 \\
Sterol esters & 9.9 & 8.1 & 10.7 & 10.8 \\
Triglycerides & 17.0 & 2.5 & 14.8 & 0.0 \\
\hline
\end{tabular}

high-throughput screening to incorporate the best mutations). The optimum temperature range of this Resinase HT is $70-85^{\circ} \mathrm{C}$. Currently, Resinase A2X and Resinase HT are used in mills from USA, Canada, China, Japan, and other countries in the Far East (where wood species with high resin content are handled). Very recently, it was shown that combining a novel biosurfactant with a lipase can reduce the concentration of a broad range of extractives in softwood TMP pulps (Dubé et al. 2008). Lipase treatments were shown to successfully reduce the triglycerides in pulps, but besides triglycerides, other disturbing compounds such as free and esterified sterols, resin acids, fatty alcohols, alkanes, etc. are also responsible for pitch problems. Thus, sterol esterases (steryl-ester acylhydrolases, E.C. 3.1.1.13), which hydrolyze fatty acid esters of sterols, were also suggested for pitch control (Calero-Rueda et al. 2004; Kontkanen et al. 2006c).

Sterol esters are often at the origin of pitch deposits, taking into account their abundance in some kinds of wood as well as their tackiness and tendency to aggregate. In addition, some enzymes classified as lipases were reported to catalyze the hydrolysis of sterol esters (Gao and Breuil 1998; Kontkanen et al. 2004). Sterol esterases have a broad substrate specificity and are capable of hydrolyzing different triglycerides and $p$-nitrophenyl esters in addition to sterol esters. These enzymes are produced in mammalian tissues and by several fungi and bacteria (Panda and Gowrishankar 2005). Fungal sterol esterases from Melanocarpus albomyces (Kontkanen et al. 2006a, c) and Ophiostoma piceae (Calero-Rueda et al. 2002, 2009) have recently been characterized from the biochemical and molecular points of view. The ability to hydrolyze sterol esters is considered to be a particular characteristic of this group of enzymes, together with the lack of the above-mentioned mobile lid in their molecular structure, as found in typical lipases (Calero-Rueda et al. 2009). These fungal esterases were tested for treating a model pitch preparation simulat- ing the TMP (Kontkanen et al. 2006c) and eucalypt pulp resin (Calero-Rueda et al. 2004). The treatments revealed that both sterol esters and triglycerides were hydrolyzed in the presence of suitable detergents, whereas only triglycerides were cleaved in their absence.

Fungal sterol esterases can be produced by heterologous expression in industrial hosts and the recombinant enzymes have been characterized (Calero-Rueda et al. 2009; Kontkanen et al. 2006a) and immobilized to increase their enzyme stability (Torres et al. 2008). The effects of a recombinant sterol esterase from $M$. albomyces on the extractives of TMP water (Table 17.3) as well as on the properties of derived paper sheets were evaluated and compared with Resinase A2X (Kontkanen et al. 2006b). Although high hydrolysis rates were reported for treatments of model pitch mixtures with sterol esterases (Calero-Rueda et al. 2004; Kontkanen et al. 2006c), only up to $18 \%$ of real sterol esters were hydrolyzed (Table 17.3).

Concerning the use of sterol esterases for pitch biocontrol, it is worth mentioning that the hydrolysis increases the amount of free sterols, which have been shown to increase the viscosity and deposition tendency of resin (Qin et al. 2003, 2004). Therefore, the complete hydrolysis of sterol esters would not be advantageous for the papermaking process (Kontkanen et al. 2006b; Qin et al. 2004). The above results show that resin deposition control by enzymatic treatments should be evaluated carefully before any large-scale application, since degradation of certain compounds may result in more unstable wood resin dispersions (Qin et al. 2004). Little is known on the enzymes involved in enzymatic degradation of sterols and resin acids despite reports of microbial degradation of these compounds, as mentioned above (Gutiérrez et al. 1999b, 2001a; Hata et al. 1998; Liss et al. 1997; Marsheck et al. 1972; Martínez-Íñigo et al. 2000). Therefore, new enzymes acting on a broader range of substrates are being investigated, including oxidoreductases, as described below. 


\section{B. Oxidative Enzymes}

Oxidoreductases are widely distributed among microbial, plant, and animal organisms. They catalyze the exchange of electrons or redox equivalents between donor and acceptor molecules, in reactions involving electron transfer, proton abstraction, hydrogen extraction, hydride transfer, oxygen insertion, or other key steps (Xu 2005). Oxidoreductases have been objects of interest in the pulp and paper industry with the aim of developing environmentally sound technologies for pulp delignification and bleaching. Among them, laccases (EC 1.10.3.2) constitute a group of oxidative enzymes which has been paid more and more attention in the recent years (Mayer and Staples 2002; Riva 2006; Rodríguez Couto and Toca Herrera 2006; Widsten and Kandelbauer 2008). Laccases are metalloenzymes containing four catalytic coppers in their molecular structure (Fig. 17.6). Due to the redox potential of the copper centers, the direct action of laccases is in principle limited to phenolic structures that only represent a small percentage in lignin

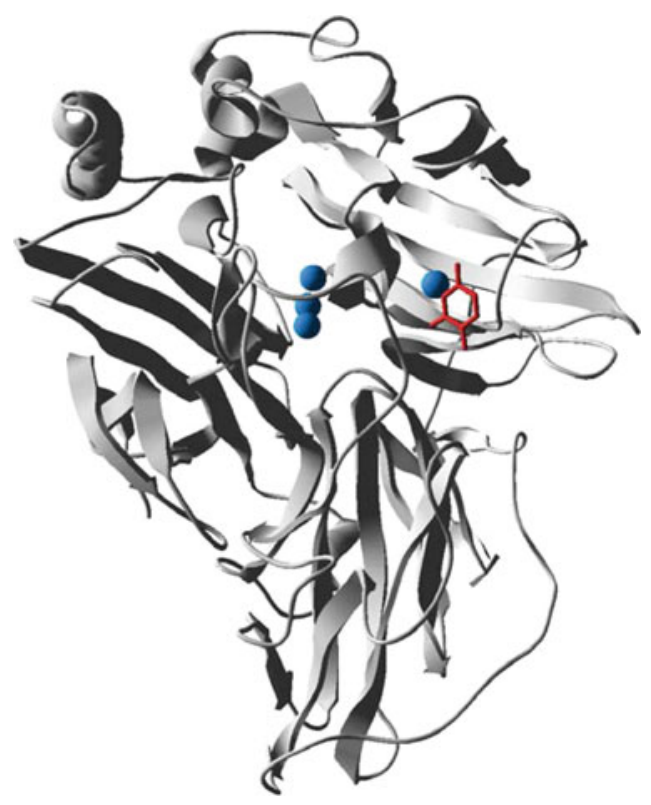

Fig. 17.6. Scheme of the molecular structure of a high redox-potential laccase, from the basidiomycete Trametes versicolor, in complex with an aromatic molecule (red) that occupies a position close to copper 1 (blue sphere, right) directly involved in electron abstraction from the substrate. The different helices and $\beta$-sheets are shown, as well as the position of the three other copper ions involved in catalysis (from PDB entry 1KYA)
(5-15\%). Therefore, high-redox-potential lignin and manganese peroxidases were more intensively studied in the beginning (about 30 years ago), regarding both lignin biodegradation and the development of biotechnological applications (Paice et al. 1995).

However, the interest in laccases as industrial biocatalysts strongly increased after discovering the effect of some synthetic compounds acting as redox mediators, including 2,2'-azinobis(3-ethylbenzothiazoline-6-sulfonic acid) (ABTS; Bourbonnais and Paice 1990) and 1-hydroxybenzotriazole (HBT; Call 1994). They expanded the action of laccase to non-phenolic substrates and increased their potential to degrade lignin and, therefore, their potential for pulp bleaching (Bourbonnais and Paice 1996; Camarero et al. 2004; Ibarra et al. 2007; Poppius-Levlin et al. 1999; Sealey et al. 1999). In addition to its action on phenolic compounds, some reactivity of laccase (e.g. from a Trametes species) was reported on polyunsaturated fatty acids (20\% decrease after $4 \mathrm{~h}$ treatment), conjugated resin acids (29\% decrease), and trilinolein $(20-35 \%$ reduction within 3 h; Karlsson et al. 2001; Zhang et al. 2002). In the reaction of laccase with trilinolein, the predominant oxidation products were monohydroperoxides, bishydroperoxides, and epoxides. Likewise, a $>30 \%$ decrease of lipophilic extractives present in softwood pulp (TMP pulping) and derived process water was reported (Buchert et al. 2002; Dubé et al. 2008; Zhang et al. 2000, 2005).

Recently, the high efficiency of laccase-mediator systems for the removal of lipophilic extractives present in pulps from different origins was described for the first time, regardless of the particular pulping process, the raw materials, or the chemical nature of the compounds to be degraded (Gutiérrez et al. 2006b); and a respective international patent application was submitted (Gutiérrez et al. 2008a). In these studies, the laccase from the basidiomycete Pycnoporus cinnabarinus was used in the presence of the mediator HBT and very efficiently removed free and conjugated sterols (95-100\% decrease) from eucalypt kraft pulp (Fig. 17.7), triglycerides, resin acids, and sterols (65$100 \%$ decrease) from spruce (TMP pulp), and fatty alcohols, alkanes, and sterols (40-100\% decrease) from flax soda pulp (Table 17.4). The removal of lipids by the laccase-HBT couple resulted in the formation of several oxidized derivatives that were absent or just present in traces in the original pulps. The total lipid content of the pulps decreased significantly, and the most problematic compounds were completely removed. In another study, this enzymatic treatment was applied as an additional stage of an industrial-type TCF sequence for bleaching 

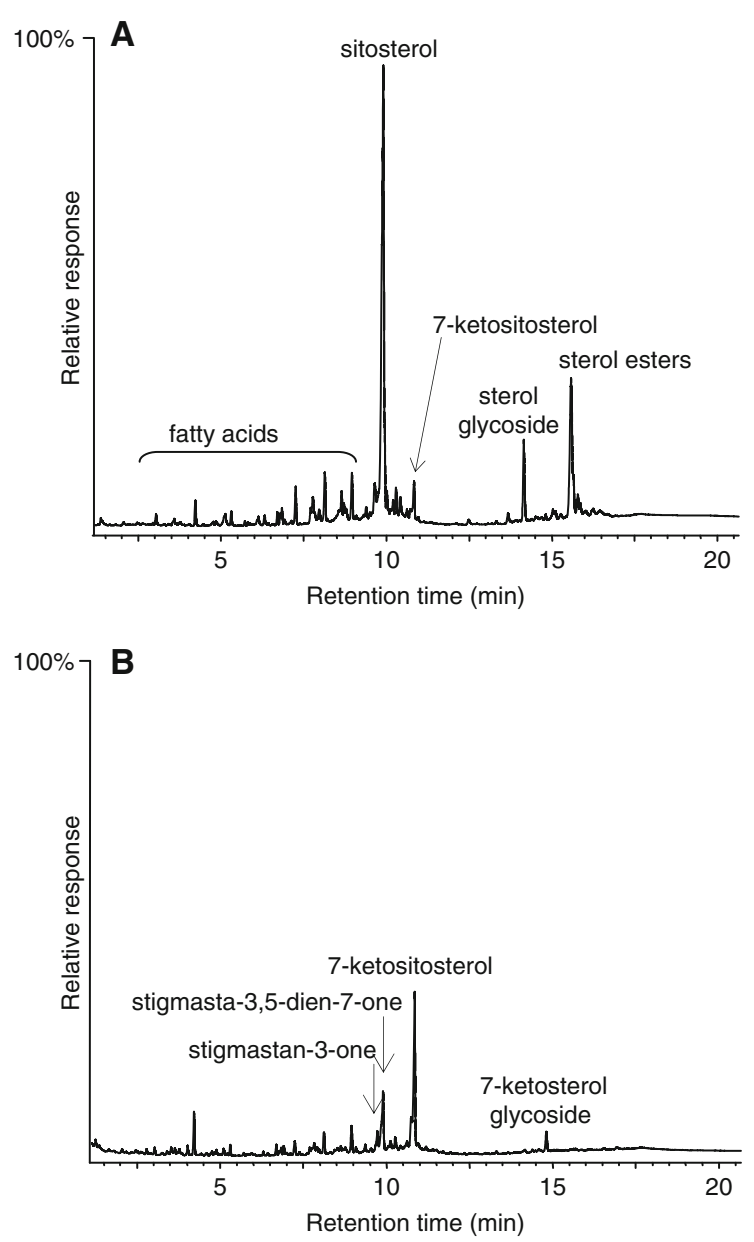

Fig. 17.7. Gas chromatography analysis of lipophilic compounds in eucalypt kraft pulp before (A) and after (B) laccase-HBT treatment (adapted from Gutiérrez et al. 2006a) eucalypt kraft pulp and resulted in the complete removal of free and conjugated sitosterol (Gutiérrez et al. 2006a). Moreover, pulp brightness was improved due to the simultaneous removal of lignin by the laccase-mediator treatment.

In another recent study, the laccase-mediator system was optimized for the removal of free sterols from E. globulus pulp using a factorial design (Valls et al. 2009; Fig. 17.8). Different operation conditions following a three-variable (laccase dose, mediator dose, reaction time) sequential statistical plan were tested. The decrease in the pulp's sterol content was related to the decrease in kappa number and to the brightness increase, as well as to the initial increase in some oxidation products of sitosterol (namely 7-ketositosterol and stigmasta-3,5-dien-7-one, whose abundance decreased again at the end of the treatment). The increase in reaction time from $1 \mathrm{~h}$ to 5 $\mathrm{h}$ strongly reduced the sterol content, while no more sterols were eliminated during the next to hours $(5-7 \mathrm{~h})$. Increasing the laccase dose from $1 \mathrm{U} / \mathrm{g}$ to $20 \mathrm{U} / \mathrm{g}$ of pulp produced a high reduction in pulp sterols, whereas an increase in the mediator (HBT) dose (from $0.5 \%$ to $2.5 \%$ of pulp weight) had only a slight influence on the removal of sterols. In this study, it was also demonstrated that sterols were more sensitive to a laccase-mediator treatment (practically $100 \%$ of sterols were removed) than to a chlorine dioxide stage ( $54 \%$ of sterols removal).

Further investigations into the chemistry of the reactions of the laccase-mediator system were carried out with the main lipophilic extractives present in hardwood, softwood, and nonwoody paper pulps (including alkanes, fatty alcohols, fatty acids, resin acids, free sterols, sterol esters, triglycerides). The reaction products were identified and quantified during the enzymatic treatment to better understand the degradation patterns in different pulps (Molina et al. 2008).

Table 17.4. Effect of the enzymatic treatment of several pulps with the laccase-HBT system on the lipophilic pulp extractives (from Gutiérrez et al. 2006b). tr Traces, nd not determined

\begin{tabular}{|c|c|c|c|c|c|c|}
\hline & \multicolumn{6}{|c|}{ Lipid content (mg/kg) } \\
\hline & \multicolumn{2}{|c|}{ Eucalypt kraft pulp } & \multicolumn{2}{|c|}{ Spruce TMP pulp } & \multicolumn{2}{|c|}{ Flax soda/AQ pulp } \\
\hline & Control & Treated & Control & Treated & Control & Treated \\
\hline Fatty acids & 48.5 & 27.9 & 116.1 & 68.3 & nd & nd \\
\hline Resin acids & - & - & 1278.4 & 400.9 & - & - \\
\hline Fatty alcohols & - & - & 18.6 & 14.9 & 121.3 & 49.7 \\
\hline Alkanes & - & - & - & - & 12.8 & 8.0 \\
\hline Steroid hydrocarbons & 14.2 & 4.9 & - & - & - & - \\
\hline Free sterols & 140.3 & 5.5 & 120.5 & 41.4 & 81.5 & - \\
\hline Steroid ketones & 9.0 & 97.2 & 7.0 & 67.0 & 2.4 & 19.1 \\
\hline Sterol glycosides & 17.1 & - & 45.0 & - & 14.0 & - \\
\hline Oxidized sterol glycosides & - & 6.9 & - & $\operatorname{tr}$ & - & 5.4 \\
\hline Waxes & - & - & - & - & 2.6 & 0.6 \\
\hline Sterol esters & 95.4 & - & 1274.6 & 218.3 & - & - \\
\hline Triglycerides & - & - & 1982.5 & 151.2 & - & - \\
\hline
\end{tabular}



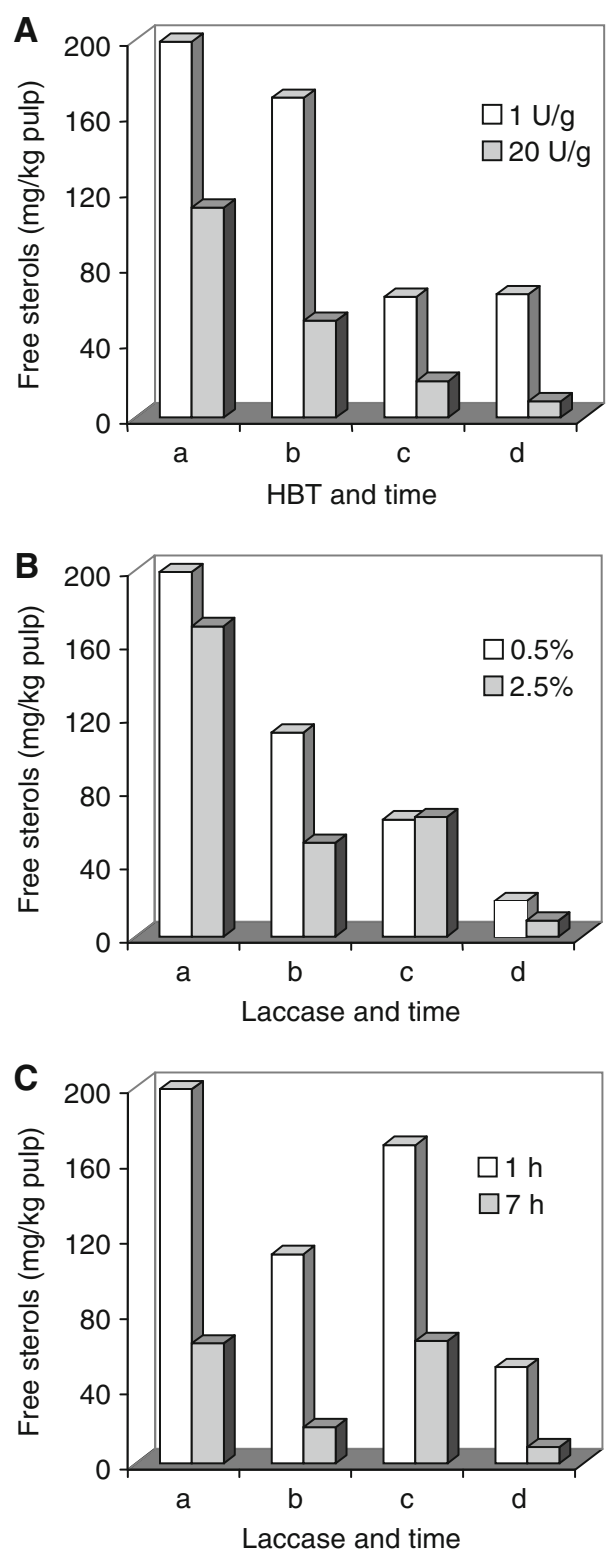

Fig. 17.8. Effect of three treatment parameters on sterol removal during the enzymatic treatment of eucalypt pulp with the laccase-HBT system, investigated using a factorial design. A Effect of laccase dose under four different combinations $(a-d)$ of the two other variables $(a 0.5 \% \mathrm{HBT}, 1 \mathrm{~h}$ reaction time; $b 2.5 \% \mathrm{HBT}, 1 \mathrm{~h}$ reaction time; $c 0.5 \% \mathrm{HBT}, 7$ $\mathrm{h}$ reaction time; $d 2.5 \% \mathrm{HBT}, 7 \mathrm{~h}$ reaction time). $\mathrm{B}$ Effect of mediator (HBT) dose under four different combinations $(a-d)$ of the two other variables $\left(a 1 \mathrm{U} \mathrm{g}^{-1}\right.$ laccase dose, $1 \mathrm{~h}$ reaction time; $b 20 \mathrm{U} \mathrm{g}^{-1}$ laccase dose, $1 \mathrm{~h}$ reaction time; $c 1 \mathrm{U} \mathrm{g}^{-1}$ laccase dose, $7 \mathrm{~h}$ reaction time; $d 20 \mathrm{U} \mathrm{g}^{-1}$ laccase dose, $7 \mathrm{~h}$ reaction time). $\mathrm{C}$ Effect of reaction time under four different combinations $(a-d)$ of the two other variables $(a 1$ $\mathrm{U} \mathrm{g}^{-1}$ laccase dose, $0.5 \% \mathrm{HBT} ; b 20 \mathrm{U} \mathrm{g}^{-1}$ laccase dose, $0.5 \%$ $\mathrm{HBT}$; $1 \mathrm{U} \mathrm{g}^{-1}$ laccase dose, $2.5 \% \mathrm{HBT}$; $d 20 \mathrm{U} \mathrm{g}^{-1}$ laccase dose, $2.5 \%$ HBT). Adapted from Valls et al. (2009)
These studies showed that a $60-100 \%$ decrease of the initial amount of unsaturated compounds (e.g. abietic acid, trilinolein, linoleic and oleic acids, sitosterol, cholesteryl palmitate, oleate, linoleate) was achieved at the end of a 2-h laccase-HBT treatment (Fig. 17.9). Likewise, a decrease of $20-40 \%$ of these unsaturated lipids was observed after treatment with laccase alone, except in the case of abietic acid (95\% decrease) and in the case of cholesteryl palmitate and sitosterol (not affected).

The latter study confirmed the finding that laccase alone can decrease the concentration of some unsaturated lipids (Karlsson et al. 2001; Zhang et al. 2002). However, the most rapid and extensive lipid modification was obtained with the laccase-mediator system. Model unsaturated lipids were largely oxidized and the dominant products detected were epoxy- and hydroxyfatty acids (Fig. 17.10A), as well as free and esterified 7-ketosterols and steroid ketones were formed from sterols and sterol esters (Figs. 17.10B and 17.11, respectively). The enzymatic reaction on sterol esters largely depended on the nature of the fatty-acyl moiety, i.e. oxidation of saturated fatty-acid esters started at the sterol moiety (Fig. 17.11A), whereas the initial attack on unsaturated fatty-acid esters occurred on the bonds (Fig. 17.11B, C). In the case of sterol linoleate (Fig. 17.11C), breakdown of the fatty acid chain proceeds via release of the so-called core aldehydes. Interestingly, no reaction products of abietic acid, trilinolein and linoleic acid were detectable despite their high reactivity and rapid disappearance in the reaction solution. Saturated lipids were not susceptible to the laccase-HBT systems, although some of them decreased when the laccase-mediator reactions were carried out in the presence of unsaturated lipids, suggesting the participation of intermediary lipid peroxyl radicals.

Since some shortcomings of HBT and related synthetic mediators (e.g. high costs, toxicity) hamper their industrial application, the search for natural compounds that could act as laccase mediators has been forced over recent years. The existence of fungal metabolites acting as redox mediators had already been suggested 15 years ago (Eggert et al. 1996; Gutiérrez et al. 1994). In this context, it was recently demonstrated by Gutiérrez et al. (2007) that three cost-effective phenolic compounds related to lignin can act as laccase mediators for the removal of lipophilic compounds from paper pulp within the frame of a TCF sequence. These natural mediators were first described as an alternative to synthetic mediators in paper pulp delignification (Camarero et al. 2007). 

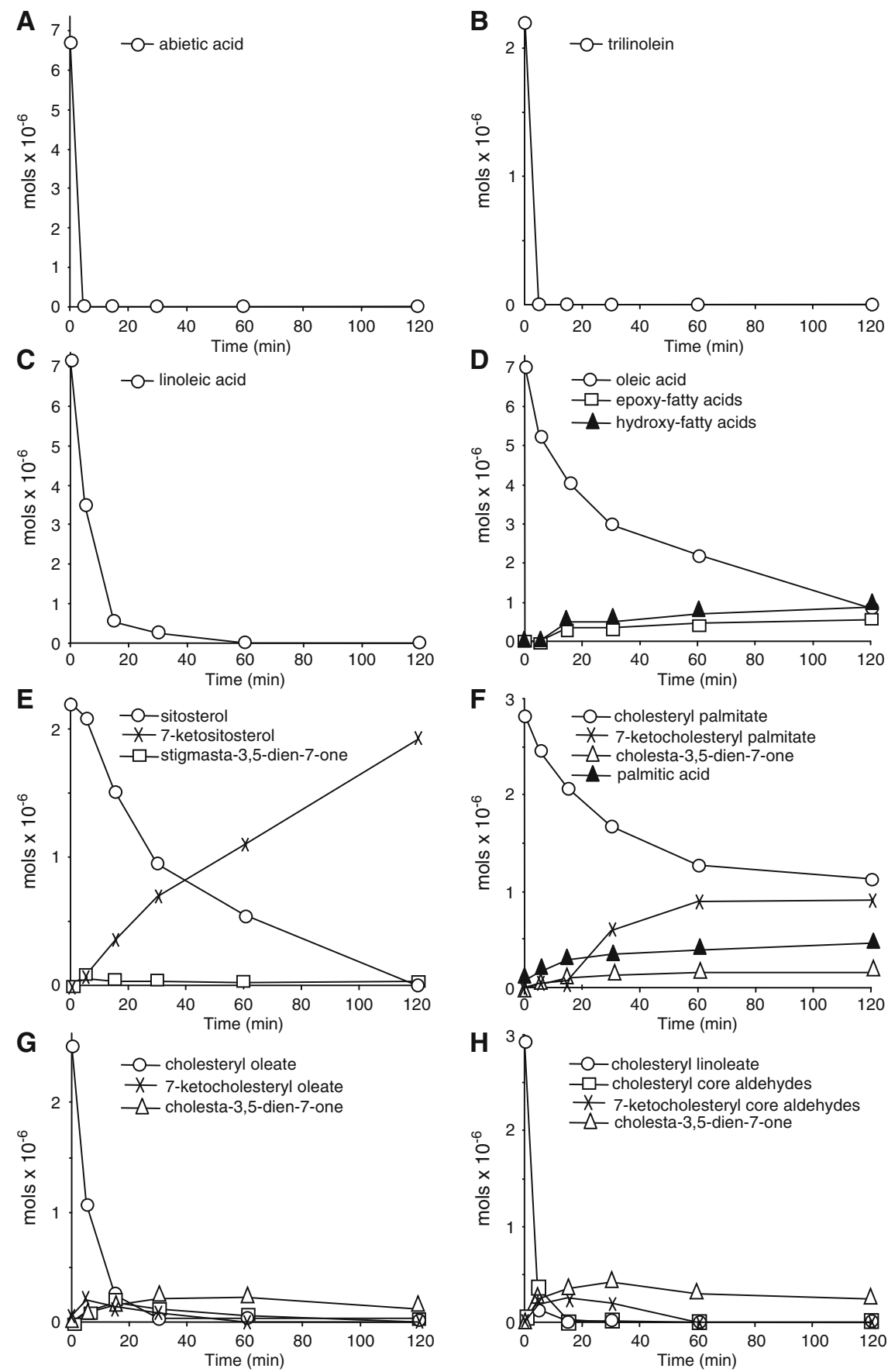

Fig. 17.9. Removal of eight model lipids and formation of oxidation products during laccase-HBT reactions: abietic acid (A), trilinolein (B), linoleic acid (C), oleic acid (D), sitosterol (E), cholesteryl palmitate (F), cholesteryl oleate (G) and cholesteryl linoleate (H). Adapted from Molina et al. (2008)

In the study mentioned above, unbleached eucalypt kraft pulp was treated with a fungal laccase in the presence of syringaldehyde, acetosyringone, and p-coumaric acid as phenolic mediators followed by a hydrogen peroxide stage
(Table 17.5). The enzymatic treatment in the presence of syringaldehyde caused the highest removal (>90\%) of free and conjugated sitosterol, similar to that attained with HBT, followed by acetosyringone ( $>60 \%$ removal), whereas 
Fig. 17.10. Main oxidation products identified by GC-MS during the reaction of oleic acid (A) and sitosterol (B) with laccaseHBT. Data from Molina et al. (2008)

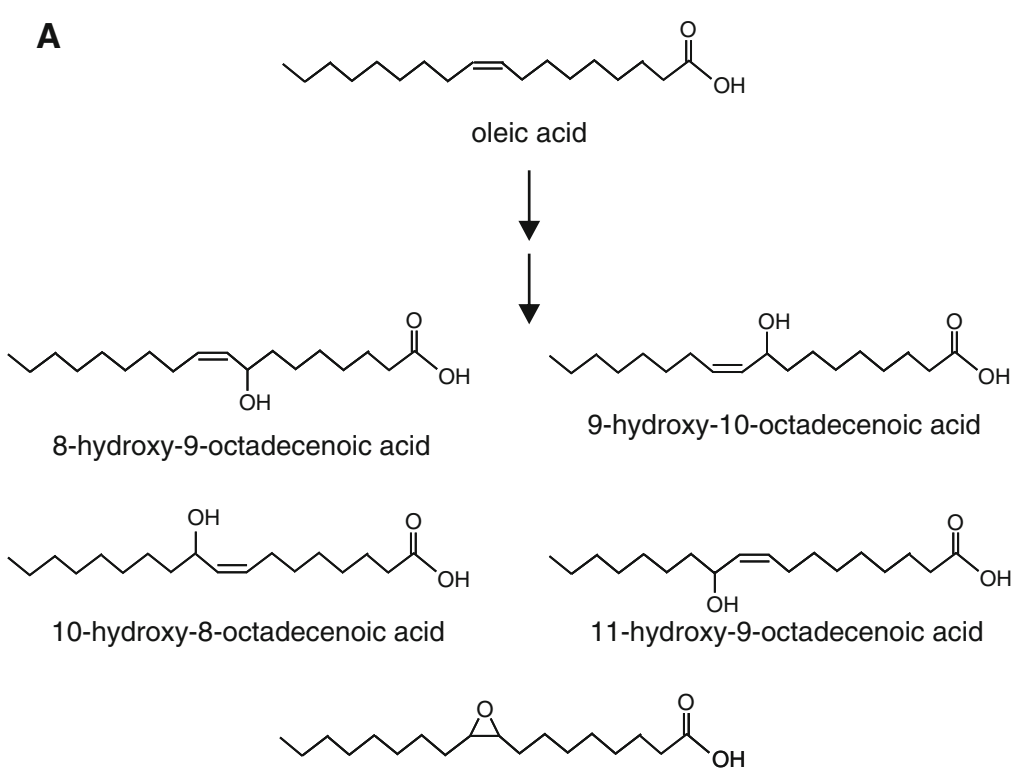

cis-9,10-epoxyoctadecenoic acid

B

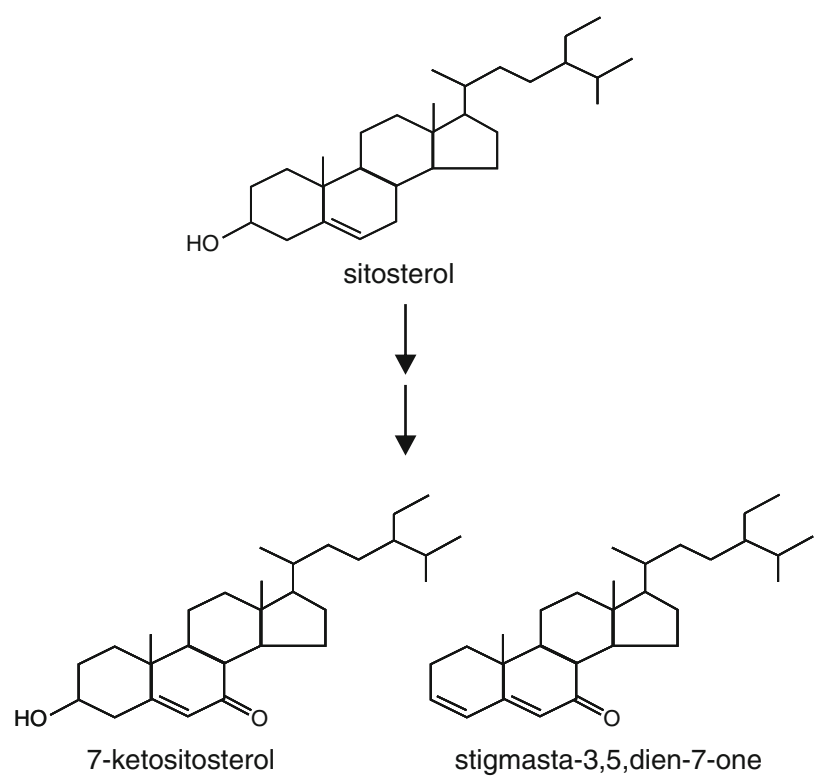

p-coumaric acid was barely effective. Pulp brightness was also improved (57-66\% ISO brightness) by the laccasemediator and subsequent peroxide treatment. The use of natural compounds as laccase mediators could make these enzymatic treatments more feasible to be applied in the pulp and paper sector. However, more knowledge is needed before this enzymatic treatment for the (simultaneous) removal of pulp pitch and lignin will be considered as a serious proposition to be implemented in the respective processes.

Finally, the use of lipoxygenases (EC 1.13.11.12), a class of non-heme iron-containing dioxygenases which catalyze the oxygenation of unsaturated fatty acids and their esters, was suggested for pitch control in softwood TMP pulps (Zhang et al. 2007).

Lipoxygenases are ubiquitous in plants, mammalians, and fungi. Despite extensive studies on their biochemical and molecular properties (Brash 1999; Saam et al. 2007), this group of enzymes has not yet been introduced into industrial processes. Nevertheless, the specific activity of lipoxygenases to oxidize linoleic acid makes them interesting for applications in the papermaking process. In the work of Zhang et al. (2007), the lipophilic extractives content of 
Fig. 17.11. Main oxidation products identified by GC-MS during the reaction of cholesteryl palmitate (A), cholesteryl oleate (B) and cholesteryl linoleate (C) with laccase-HBT. Data from Molina et al. (2008)
A

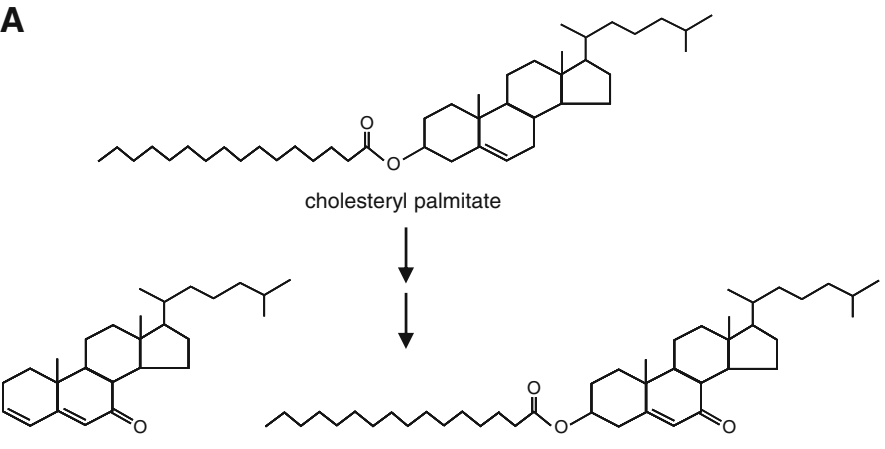

B<smiles>CCCCCCCCCCCCCCC(O)OC1CCC2(C)C(=CCC3C4CCC5C(C(C)CCCC(C)C)CCC5C4CCC32)C1</smiles>

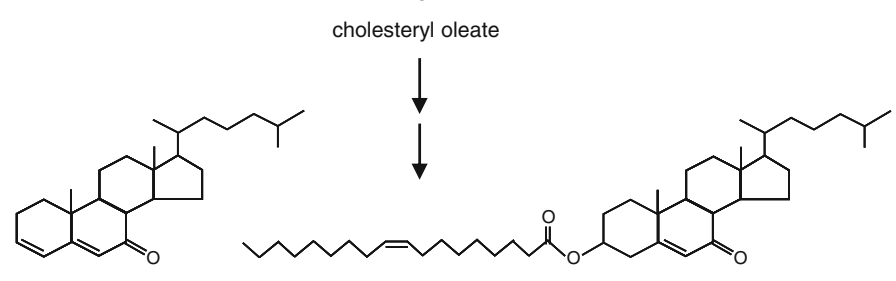
cholesta-3,5-dien-7-one 7-ketocholesteryl oleate

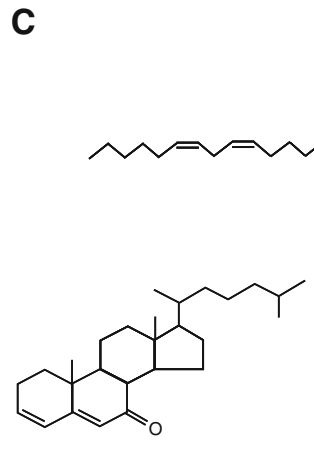

cholesta-3,5-dien-7-one

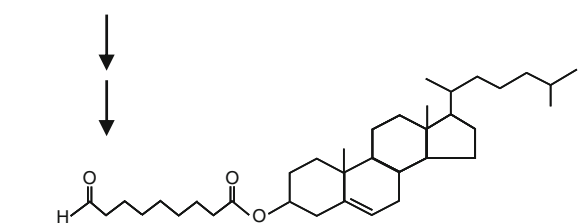
cholesteryl 9-oxononanoate<smiles>CC(C)CCCC(C)C1CCC2C3C(=O)C=C4CC(OC(=O)CCCCCCC=O)CCC4(C)C3CCC12C</smiles>

7-ketocholesteryl 9-oxononanoate

TMP pulp samples was reduced by more than $25 \%$ after a 2-h treatment with soybean lipoxygenase. The activity of lipoxygenase towards wood extractives was determined by using a mixture extracted from TMP and the enzyme was found to exhibit a significant activity towards all these wood extractives. However, it turned out that some of the extractives (such as resin acids) and lignin fragments have inhibitory effects on lipoxygenase-catalyzed reactions with linoleic acid. An earlier study published in a patent by Novozymes had suggested the possibility of using lipoxygenases to reduce a model wood "pitch" mixture (Borch et al. 2003). Further studies on lipoxygenases for pitch biocontrol are currently under investigation (Nguyen et al. 2007). 
Table 17.5. Effect of three "natural" mediators on the removal of lipids during laccase treatment of eucalypt pulp, followed by an $\mathrm{H}_{2} \mathrm{O}_{2}$ stage, compared with the synthetic mediator HBT and controls without laccase as well as with laccase but without mediator (from Gutiérrez et al. 2007). SAD Syringaldehyde, ACS acetosyringone, PCA p-coumaric acid

\begin{tabular}{|c|c|c|c|c|c|c|}
\hline & \multicolumn{6}{|c|}{ Lipid content (mg/kg) } \\
\hline & Control & Laccase & SAD & ACS & PCA & HBT \\
\hline Total free sterols & 273 & 280 & 25 & 113 & 230 & 27 \\
\hline Sitosterol & 222 & 226 & 19 & 83 & 186 & 14 \\
\hline Stigmastanol & 42 & 44 & 4 & 25 & 37 & 12 \\
\hline Fucosterol & 9 & 10 & 2 & 5 & 7 & 1 \\
\hline Total oxidized sterols & 32 & 53 & 7 & 10 & 43 & 69 \\
\hline Stigmastan-3-one & 0 & 0 & 0 & 1 & 0 & 2 \\
\hline Stigmasta-3,5-dien-7-one & 4 & 4 & 2 & 7 & 8 & 17 \\
\hline $7 \alpha$-Hydroxysitosterol & 7 & 13 & 1 & 1 & 6 & 8 \\
\hline $7 \beta$-Hydroxysitosterol & 12 & 21 & 1 & 1 & 9 & 4 \\
\hline Sitostanetriol & 3 & 5 & 2 & 0 & 13 & 5 \\
\hline 7-Oxositosterol & 5 & 10 & 1 & 1 & 7 & 34 \\
\hline Total sterol glycosides & 27 & 27 & 2 & 12 & 24 & 5 \\
\hline Sitosteryl $3 \beta$-D-glucopyranoside & 27 & 27 & 2 & 12 & 24 & 2 \\
\hline 7-Oxositosteryl-3 $\beta$-D-glucopyranoside & 0 & 0 & 0 & 0 & 0 & 2 \\
\hline Sterol esters & 90 & 57 & 7 & 43 & 57 & 2 \\
\hline Steroid hydrocarbons & 22 & 21 & 3 & 11 & 15 & 8 \\
\hline Total & 444 & 438 & 45 & 189 & 369 & 110 \\
\hline
\end{tabular}

\section{Summary and Conclusions}

Wood lipids surviving the pulping and bleaching processes have a high tendency to form pitch deposits, resulting in economic losses and operational troubles during pulp and paper manufacturing. The impact of these pitch problems has increased during recent years due to the latest developments in the sector, such as the closure of water circuits and the use of TCF bleaching sequences. In particular fatty acids, fatty alcohols, resin acids, hydrocarbons, steroids, triterpenoids, and triglycerides are among these lipophilic wood extractives forming pitch deposits. Therefore, clean biotechnological technologies capable of modifying these compounds are highly desirable for reducing these problems. In the 1990s, two biotechnological applications for pitch control were successfully developed and applied at full mill-scale in various parts of the world. The fungal method for pitch control using an albino strain of the ascomycete Ophiostoma piliferum (a sapstain fungus) was the first successful example of using a living organism in the pulp and paper manufacturing process (particularly in mechanical softwood pulping). Likewise, the enzymatic method for pitch control using lipase was the first successful example of the use of an isolated enzyme in the papermaking process. In both cases, triglycerides - representing the main cause of pitch problems - are preferably removed. Since then, work has focused on finding biotechnological solutions to get rid of other lipophilic extractives, such as free and esterified sterols, as well as resin acids.

Biotechnological processes based on selective white-rot fungi would have certain advantages compared to sapstain fungi. The latter easily degrade some lipophilic extractives, such as triglycerides and fatty acids, and they can even hydrolyze sterol esters; however, free sterols, triterpenols and resin acids are too recalcitrant for an efficient degradation by sapstain fungi, and better removals have been obtained with whiterot basidiomycetes. In addition to the advantages directly resulting from the removal of wood extractives, wood chip pretreatment with certain white-rot fungi can also decrease the amount of lignin, a process known as biopulping, enabling substantial savings in the energy required for obtaining mechanical pulps. The applicability of white-rot fungi in wood pulping will greatly depend on their effects on pulp yield and properties. Thus fungal attack of cellulose in pulp fibers would be highly undesirable as it causes a reduction in yield and pulp strength properties. Therefore, these biodepitching/biopulping treatments need to be applied under controlled conditions (including treatment duration) to attain 
a maximal removal of lipids and lignin with a minimal deterioration of fibers and hydrolysis of cellulose. Moreover, an energy-intensive pretreatment of wood chips (such as steaming for partial sterilization) is often required for successful colonization by white-rot fungi, while sapstain fungi are characterized by their ability to colonize fresh wood without the need of any pretreatment.

The use of enzymes to remove extractives from pulp has clear advantages compared to the use of fungal inocula, such as shorter treatment times and higher specificity. Commercial lipases are successful in the hydrolysis of triglycerides in softwood pulps and are currently used in different types of mills. Recently, some promising results have been reported in the use of oxidative enzymes, particularly laccases in combination with suitable redox mediators. They are effective towards several lipophilic extractives, such as fatty acids, resin acids, free and conjugated sterols, and triglycerides. High-redox-potential laccases are characteristic for white-rot fungi and, as in the case of the latter, a double benefit can be obtained from their application on pulps in the presence of redox mediators. Laccase-mediator systems both permit the effective removal of pulp lipids (decreasing the pitch problem) and improve pulp delignification (resulting in a higher brightness and stability) using the same enzymatic preparation. The costs and environmental concerns associated with the use of synthetic mediators (such as NOH-type compounds) could be overcome in the future by using natural mediators, e.g. lignin-related phenolics obtained from easily available sources (such as pulping liquors), along with reasonably priced enzymes produced by genetically engineered organisms.

Acknowledgements The authors thank Kim Borch (Novozymes, Bagsvaerd, Denmark) for information on the molecular structure of commercial lipase and its thermal stabilization, Roberta Farrell (Waikato University, Hamilton, New Zealand) for images of wild and albino Ophiostoma piliferum strains, María Jesús Ortega (Soria, Spain) for the wood resin image, and Javier Romero (ENCE, Pontevedra, Spain) for the illustration of pitch deposits. This work was supported by the Spanish projects AGL2008-00709 and BIO2008-01533 and by the BIORENEW project of the European Union (contract NMP2-CT-2006-026456).

\section{References}

Akhtar M, Scott GM, Swaney RE, Shipley DF (2000) Biomechanical pulping: a mill-scale evaluation. Resour Conserv Recycl 28:241-252

Allen LH (2000a) Pitch control in paper mills. In: Back EL, Allen LH (eds) Pitch control, wood resin and deresination. TAPPI, Atlanta, pp 307-328

Allen LH (2000b) Pitch control in pulp mills. In: Back EL, Allen LH (eds) Pitch control, wood resin and deresination. TAPPI, Atlanta, pp 265-288

Back EL, Allen LH (2000) Pitch control, wood resin and deresination. TAPPI, Atlanta

Bajpai P (1999) Application of enzymes in the pulp and paper industry. Biotechnol Progr 15:147-157

Bajpai P, Bajpai PK, Akhtar M, Jauhari MB (2001) Biokraft pulping of eucalyptus with selected lignin-degrading fungi. J Pulp Paper Sci 27:235-239

Bajpai P, Anand A, Bajpai PK (2006) Bleaching with ligninoxidizing enzymes. Biotechnol Annu Rev 12:349-378

Bergelin E, Holmbom B (2003) Deresination of birch kraft pulp in bleaching. J Pulp Paper Sci 29:29-34

Bergelin E, Moller R, Holmbom B (2005) Analysis of pitch and deposit samples in kraft pulp production. Pap Puu Pap Tim 87:399-403

Blanchette RA (1995) Degradation of the lignocellulose complex in wood. Can J Bot 73:S999-S1010

Borch K, Franks N, Lund H, Xu H, Luo J (2003) Oxidizing enzymes in the manufacturing of paper materials. Patent US 2003-0124710 A1

Bornscheuer U, Bessler C, Srinivas R, Hari KS (2002) Optimizing lipases and related enzymes for efficient application. Trends Biotechnol 20:433-437

Bourbonnais R, Paice MG (1990) Oxidation of non-phenolic substrates. An expanded role for laccase in lignin biodegradation. FEBS Lett 267:99-102

Bourbonnais R, Paice MG (1996) Enzymatic delignification of kraft pulp using laccase and a mediator. Tappi J 79:199-204

Brash AR (1999) Lipoxygenases: occurrence, functions, catalysis, and acquisition of substrate. J Biol Chem 274:23679-23682

Breuil C, Iverson S, Gao Y (1998) Fungal treatment of wood chips to remove extractives. In: Young RA, Akhtar M (eds) Environmentally friendly technologies for the pulp and paper industry. TAPPI, Atlanta, pp 541-566

Brush T, Farrell RL, Ho C (1994) Biodegradation of wood extractives from Southern and Yellow pine by Ophiostoma piliferum. Tappi J 77:155-159

Buchert J, Mustranta A, Tamminen T, Spetz P, Holmbom B (2002) Modification of spruce lignans with Trametes hirsuta laccase. Holzforschung 56:579-584

Burnes TA, Blanchette RA, Farrell RL (2000) Bacterial biodegradation of extractives and patterns of bordered pit membrane attack in pine wood. Appl Environ Microbiol 66:5201-5205

Calero-Rueda O, Plou FJ, Ballesteros A, Martínez AT, Martínez MJ (2002) Production, isolation and characterization of a sterol esterase from Ophiostoma piceae. BBA Proteins Proteomics 1599:28-35 
Calero-Rueda O, Gutiérrez A, del Río JC, Prieto A, Plou FJ, Ballesteros A, Martínez AT, Martínez MJ (2004) Hydrolysis of sterol esters by an esterase from Ophiostoma piceae: Application for pitch control in pulping of Eucalyptus globulus wood. Int J Biotechnol 6:367-375

Calero-Rueda O, Barba V, Rodríguez E, Plou F, Martínez AT, Martínez MJ (2009) Study of a sterol esterase secreted by Ophiostoma piceae: Sequence, model and biochemical properties. Biochim Biophys Acta 1794:1099-1106

Call H-P (1994) Verfahren zur Veränderung, Abbau oder Bleichen von Lignin, ligninhaltigen Materialien oder ähnlichen Stoffen. Patent WO 94/29510

Camarero S, García O, Vidal T, Colom J, del Río JC, Gutiérrez A, Gras JM, Monje R, Martínez MJ, Martínez AT (2004) Efficient bleaching of non-wood highquality paper pulp using laccase-mediator system. Enzyme Microb Technol 35:113-120

Camarero S, Ibarra D, Martínez AT, Romero J, Gutiérrez A, del Río JC (2007) Paper pulp delignification using laccase and natural mediators. Enzyme Microb Technol 40:1264-1271

Chen S, Lin Y, Zhang Y, Wang XH, Yang JL (2001) Enzymatic pitch control at nanping paper mill. Tappi J 84:44-47

Chen T, Wang Z, Gao Y, Breuil C, Hatton JV (1994) Wood extractives and pitch problems: Analysis and partial removal by biological treatment. Appita 47:463-466

Chen T, Wang Z, Zhou Y, Breuil C, Aschim OK, Yee E, Nadeau L (1995) Using solid-phase extraction to assess why aspen causes more pitch problems than softwoods in kraft pulping. Tappi J 78:143-149

del Río JC, Gutiérrez A (2006) Chemical composition of abaca (Musa textilis) leaf fibers used for manufacturing of high quality paper pulps. J Agric Food Chem 54:4600-4610

del Río JC, Gutiérrez A, González-Vila FJ, Martín F, Romero J (1998) Characterization of organic deposits produced in the Kraft pulping of Eucalyptus globulus wood. J Chromatogr 823:457-465

del Río JC, Gutiérrez A, González-Vila FJ (1999) Analysis of impurities occurring in a totally-chlorine freebleached Kraft pulp. J Chromatogr 830:227-232

del Río JC, Romero J, Gutiérrez A (2000) Analysis of pitch deposits produced in Kraft pulp mills using a totally chlorine free bleaching sequence. J Chromatogr A 874:235-245

Dorado J, Claassen FW, Lenon G, van Beek TA, Wijnberg JBPA, Sierra-Alvarez R (2000a) Degradation and detoxification of softwood extractives by sapstain fungi. Bioresour Technol 71:13-20

Dorado J, Claassen FW, van Beek TA, Lenon G, Wijnberg JBPA, Sierra-Alvarez R (2000b) Elimination and detoxification of softwood extractives by white-rot fungi. J Biotechnol 80:231-240

Dorado J, van Beek TA, Claassen FW, Sierra-Alvarez R (2001) Degradation of lipophilic wood extractive constituents in Pinus sylvestris by the white-rot fungi Bjerkandera sp. and Trametes versicolor. Wood Sci Technol 35:117-125

Dubé E, Shareck F, Hurtubise Y, Beauregard M, Daneault C (2008) Enzyme-based approaches for pitch control in thermomechanical pulping of softwood and pitch removal in process water. J Chem Technol Biotechnol 83:1261-1266

Eberhardt TL, Han JS, Micales JA, Young RA (1994) Decay resistance in conifer seed cones - role of resin acids as inhibitors of decomposition by white-rot fungi. Holzforschung 48:278-284

Eggert C, Temp U, Dean JFD, Eriksson K-EL (1996) A fungal metabolite mediates degradation of nonphenolic lignin structures and synthetic lignin by laccase. FEBS Lett 391:144-148

Ekman R (2000) Resin during storage and its biological treatment. In: Back EL, Allen LH (eds) Pitch control, wood resin and deresination. Tappi, Atlanta, pp 185-204

Ekman R, Holmbom B (2000) The chemistry of wood resin. In: Back EL, Allen LH (eds) Pitch control, wood resin and deresination. TAPPI, Atlanta, pp 37-76

Farrell RL (2007) Cartapip/Sylvanex ${ }^{\text {TM }}$ : Ophiostoma fungal product for commercial pulp and paper and solid wood applications. Proc Int Congr Biotechnol Pulp Pap Indust 10:63-64

Farrell RL, Blanchette RA, Brush TS, Hadar Y, Iverson S, Krisa K, Wendler PA, Zimmerman W (1993) Cartapip $^{\mathrm{TM}}$ : a biopulping product for control of pitch and resin acid problems in pulp mills. J Biotechnol 30:115-122

Farrell RL, Hata K, Wall MB (1997) Solving pitch problems in pulp and paper processes by the use of enzymes and fungi. Adv Biochem Eng Biotechnol 57:197-212

Fengel D, Wegener G (1984) Wood: chemistry, ultrastructure, reactions. De Gruyter, Berlin

Fischer K, Messner K (1992a) Adsorption of lipase on pulp fibers during biological pitch control in paper industry. Enzyme Microb Technol 14:470-473

Fischer K, Messner K (1992b) Biological pitch reduction of sulfite pulp on pilot scale. In: Kuwahara M, Shimada M (eds) Biotechnology in the pulp and paper industry. UNI, Kyoto, pp 169-174

Fischer K, Puchinger L, Schloffer K (1993) Enzymatic pitch control of sulfite pulp on pilot scale. J Biotechnol 27:341-348

Freire CSR, Silvestre AJD, Neto CP (2002) Identification of new hydroxy fatty acids and ferulic acid esters in the wood of Eucalyptus globulus. Holzforschung 56:143-149

Freire CSR, Silvestre AJD, Neto CP (2005) Lipophilic extractives in Eucalyptus globulus kraft pulps. Behavior during ECF bleaching. J Wood Chem Technol 25:67-80

Freire CSR, Silvestre AJD, Neto CP, Evtuguin DV (2006) Effect of oxygen, ozone and hydrogen peroxide bleaching stages on the contents and composition of extractives of Eucalyptus globulus kraft pulps. Bioresour Technol 97:420-428

Fujita Y, Awaji H, Matsukura M, Hata K (1991) Enzymic pitch control in papermaking process. Kami $\mathrm{Pa}$ Gikyoshi 45:905-921

Fujita Y, Awaji H, Taneda H, Matsukura M, Hata K, Shimoto H, Sharyo M, Sakaguchi H, Gibson K (1992) Recent advances in enzymic pitch control. Tappi J 75:117-122 
Gao Y, Breuil C (1998) Properties and substrate specificities of an extracellular lipase purified from Ophiostoma piceae. World J Microbiol Biotechnol 14:421-429

Gutiérrez A, del Río JC (2001) Gas chromatography-mass spectrometry demonstration of steryl glycosides in eucalypt wood, kraft pulp and process liquids. Rapid Commun Mass Spectrom 15:2515-2520

Gutiérrez A, del Río JC (2003a) Lipids from flax fibers and their fate in alkaline pulping. J Agric Food Chem 51:4965-4971

Gutiérrez A, del Río JC (2003b) Lipids from flax fibers and their fate in alkaline pulping (vol 51, pg 4965, 2003). J Agric Food Chem 51:6911-6914

Gutiérrez A, del Río JC (2005) Chemical characterization of pitch deposits produced in the manufacturing of high-quality paper pulps from hemp fibers. Bioresour Technol 96:1445-1450

Gutiérrez A, Caramelo L, Prieto A, Martínez MJ, Martínez AT (1994) Anisaldehyde production and aryl-alcohol oxidase and dehydrogenase activities in ligninolytic fungi from the genus Pleurotus. Appl Environ Microbiol 60:1783-1788

Gutiérrez A, del Río JC, González-Vila FJ, Romero J (1998) Variation in the composition of wood extractives from Eucalyptus globulus during seasoning. J Wood Chem Technol 18:439-446

Gutiérrez A, del Río JC, González-Vila FJ, Martín F (1999a) Chemical composition of lipophilic extractives from Eucalyptus globulus Labill. wood. Holzforschung 53:481-486

Gutiérrez A, del Río JC, Martínez MJ, Martínez AT (1999b) Fungal degradation of lipophilic extractives in Eucalyptus globulus wood. Appl Environ Microbiol 65:1367-1371

Gutiérrez A, Martínez MJ, del Río JC, Romero J, Canaval J, Lenon G, Martínez AT (2000) Fungal pretreatment of Eucalyptus wood can strongly decreases the amount of lipophilic extractives during chlorine-free kraft pulping. Environ Sci Technol 34:3705-3709

Gutiérrez A, del Río JC, Martínez MJ, Martínez AT (2001a) The biotechnological control of pitch in paper pulp manufacturing. Trends Biotechnol 19:340-348

Gutiérrez A, Romero J, del Río JC (2001b) Lipophilic extractives from Eucalyptus globulus pulp during kraft cooking followed by TCF and ECF bleaching. Holzforschung 55:260-264

Gutiérrez A, Romero J, del Río JC (2001c) Lipophilic extractives in process waters during manufacturing of totally chlorine free kraft pulp from eucalypt wood. Chemosphere 44:1237-1242

Gutiérrez A, Rodríguez IM, del Río JC (2004) Chemical characterization of lignin and lipid fractions in kenaf bast fibers used for manufacturing high-quality papers. J Agric Food Chem 52:4764-4773

Gutiérrez A, del Río JC, Ibarra D, Rencoret J, Romero J, Speranza M, Camarero S, Martínez MJ, Martínez AT (2006a) Enzymatic removal of free and conjugated sterols forming pitch deposits in environmentally sound bleaching of eucalypt paper pulp. Environ Sci Technol 40:3416-3422
Gutiérrez A, del Río JC, Rencoret J, Ibarra D, Martínez AT (2006b) Main lipophilic extractives in different paper pulp types can be removed using the laccase-mediator system. Appl Microbiol Biotechnol 72:845-851

Gutiérrez A, Rodríguez IM, del Río JC (2006c) Chemical characterization of lignin and lipid fractions in industrial hemp bast fibers used for manufacturing high-quality paper pulps. J Agric Food Chem 54:2138-2144

Gutiérrez A, Rencoret J, Ibarra D, Molina S, Camarero S, Romero J, del Río JC, Martínez AT (2007) Removal of lipophilic extractives from paper pulp by laccase and lignin-derived phenols as natural mediators. Environ Sci Technol 41:4124-4129

Gutiérrez A, del Río JC, Rencoret J, Ibarra D, Speranza AM, Camarero S, Martínez MJ, Martínez AT (2008a) Mediator-enzyme system for controlling pitch deposits in pulp and paper production. US Patent 10080210393, European Patent EP 1908876 A1

Gutiérrez A, Rodríguez IM, del Río JC (2008b) Chemical composition of lipophilic extractives from sisal (Agave sisalana) fibers. Ind Crops Prod 28:81-87

Hasan F, Shah AA, Hameed A (2006) Industrial applications of microbial lipases. Enzyme Microb Technol 39:235-251

Hata K, Matsukura M, Taneda H, Fujita Y (1996) Mill-scale application of enzymatic pitch control during paper production. In: Viikari L, Jeffries TW (eds) Enzymes for pulp and paper processing. ACS, Washington, pp 280-296

Hata K, Matsukura M, Fujita Y, Toyota K, Taneda H (1998) Biodegradation of resin acids in pulp and paper industry: application of microorganisms and their enzymes. ACS Sym Ser 687:27-40

Held BW, Thwaites JM, Farrell RL, Blanchette RA (2003) Albino strains of Ophiostoma species for biological control of sapstaining fungi. Holzforschung 57:237-242

Ibarra D, Chvez MI, Rencoret J, del Río JC, Gutiérrez A, Romero J, Camarero S, Martínez MJ, JimenezBarbero J, Martínez AT (2007) Structural modification of eucalypt pulp lignin in a totally chlorine free bleaching sequence including a laccase-mediator stage. Holzforschung 61:634-646

Jansson MB, Wormald P, Dahlman O (1995) Reactions of wood extractives during ECF and TCF bleaching of kraft pulp. Pulp Paper Can 96:T134-T137

Josefsson P, Nilsson F, Sundstrom L, Norberg C, Lie E, Jansson MB, Henriksson G (2006) Controlled seasoning of Scots pine chips using an albino strain of Ophiostoma. Indust Eng Chem 45:2374-2380

Kallioinen A, Vaari A, Ratto M, Konn J, Siikaaho M, Viikari L (2003) Effects of bacterial treatments on wood extractives. J Biotechnol 103:67-76

Karlsson S, Holmbom B, Spetz P, Mustranta A, Buchert J (2001) Reactivity of Trametes laccases with fatty and resin acids. Appl Microbiol Biotechnol 55:317-320

Kontkanen H, Tenkanen M, Fagerstrom R, Reinikainen T (2004) Characterisation of steryl esterase activities in commercial lipase preparations. J Biotechnol 108:51-59 
Kontkanen H, Reinikainen T, Saloheimo M (2006a) Cloning and expression of a Melanocarpus albomyces steryl esterase gene in Pichia pastoris and Trichoderma reesei. Biotechnol Bioeng 94:407-415

Kontkanen H, Saloheimo M, Pere J, Miettinen-Oinonen A, Reinikainen T (2006b) Characterization of Melanocarpus albomyces steryl esterase produced in Trichoderma reesei and modification of fibre products with the enzyme. Appl Microbiol Biotechnol 72:696-704

Kontkanen H, Tenkanen M, Reinikainen T (2006c) Purification and characterisation of a novel steryl esterase from Melanocarpus albomyces. Enzyme Microb Technol 39:265-273

Leach JM, Thakore AN (1976) Toxic constituents in mechanical pulping effluents. Tappi 59:129-132

Liss SN, Bicho PA, Saddler JN (1997) Microbiology and biodegradation of resin acids in pulp mill effluents: a minireview. Can J Microbiol 43:599-611

Marsheck WJ, Kraychy S, Muir RD (1972) Microbial degradation of sterols. Appl Microbiol 23:72-77

Martínez AT, Speranza M, Ruiz-Dueñas FJ, Ferreira P, Camarero S, Guillén F, Martínez MJ, Gutiérrez A, del Río JC (2005) Biodegradation of lignocellulosics: Microbiological, chemical and enzymatic aspects of fungal attack to lignin. Intern Microbiol 8:195-204

Martínez MJ, Barrasa JM, Gutiérrez A, del Río JC, Martínez AT (1999) Fungal screening for biological removal of extractives from Eucalyptus globulus Labill. wood. Can J Bot 77:1513-1522

Martínez-Íñigo MJ, Immerzeel P, Gutiérrez A, del Río JC, Sierra-Alvarez R (1999) Biodegradability of extractives in sapwood and heartwood from Scots pine by sapstain and white-rot fungi. Holzforschung 53:247-252

Martínez-Íñigo MJ, Gutiérrez A, del Río JC, Martínez MJ, Martínez AT (2000) Time course of fungal removal of lipophilic extractives from Eucalyptus globulus Labill. wood. J Biotechnol 84:119-126

Matsukura M, Fujita Y, Sakaguchi H (1990) On the use of Resinase $^{\text {TM }}$ A for pitch control. Novo Publ A 6122:1-7

Mayer AM, Staples RC (2002) Laccase: new functions for an old enzyme. Phytochemistry 60:551-565

Molina S, Rencoret J, del Río JC, Lomascolo A, Record E, Martínez AT, Gutiérrez A (2008) Oxidative degradation of model lipids representative for main paper pulp lipophilic extractives by the laccase-mediator system. Appl Microbiol Biotechnol 80:211-222

Morin C, Tanguay P, Breuil C, Yang DQ, Bernier L (2006) Bioprotection of spruce logs against sapstain using an albino strain of Ceratocystis resinifera. Phytopathology 96:526-533

Morrison WHI, Akin DE (2001) Chemical composition of components comprising bast tissue in flax. J Agric Food Chem 49:2333-2338

Nguyen D, Zhang X, Paice MG, Tsang A, Renaud S (2007) Microplate enzyme assay for screening lipoxygenases to degrade wood extractives. Biocatal Biotransform 25:202-210

Paice MG, Bourbonnais R, Reid ID, Archibald FS, Jurasek L (1995) Oxidative bleaching enzymes: a review. J Pulp Paper Sci 21:J280-J284
Panda T, Gowrishankar BS (2005) Production and applications of esterases. Appl Microbiol Biotechnol 67:160-169

Poppius-Levlin K, Wang W, Tamminen T, Hortling B, Viikari L, Niku-Paavola M-L (1999) Effects of laccase/HBT treatment on pulp and lignin structures. J Pulp Paper Sci 25:90-94

Qin M, Hannuksela T, Holmbom B (2003) Physico-chemical characterization of TMP resin and related model mixtures. Colloid Surf A 221:243-254

Qin M, Hannuksela T, Holmbom B (2004) Deposition tendency of TMP resin and related model mixtures. J Pulp Paper Sci 30:279-283

Rencoret J, Gutiérrez A, del Río JC (2007) Lipid and lignin composition of woods from different eucalypt species. Holzforschung 61:165-174

Riva S (2006) Laccases: blue enzymes for green chemistry. Trends Biotechnol 24:219-226

Rocheleau MJ, Sitholé BB, Allen LH, Noel Y (1999) Fungal treatment of aspen for wood resin reduction: effect on aged aspen wood chips at room temperature and at $5{ }^{\circ} \mathrm{C}$. Holzforschung 53:16-20

Rodríguez Couto S, Toca Herrera JL (2006) Industrial and biotechnologcial applications of laccases: a review. Biotechnol Adv 24:500-513

Saam J, Ivanov I, Walther M, Holzhutter HG, Kuhn H (2007) Molecular dioxygen enters the active site of 12/15-lipoxygenase via dynamic oxygen access channels. Proc Natl Acad Sci USA 104:13319-13324

Sealey J, Ragauskas AJ, Elder TJ (1999) Investigations into laccase-mediator delignification of kraft pulps. Holzforschung 53:498-502

Silvério FO, Barbosa LCA, Maltha CRA, Fidêncio PH, Cruz MP, Veloso DP, Milanez AF (2008) Effect of storage time on the composition and content of wood extractives in Eucalyptus cultivated in Brazil. Bioresour Technol 99:4878-4886

Silvestre AJD, Pereira CCL, Neto CP, Evtuguin DV, Duarte AC, Cavaleiro JAS, Furtado FP (1999) Chemical composition of pitch deposits from ECF Eucalyptus globulus bleached kraft pulp mill: its relationship with wood extractives and additives in process streams. Appita J 52:375-382

Sitholé BB, Ambayec B, Lapierre L, Allen L (2009) A study of polymerization of aspen (Populus) wood lipophilic extractives by SEC and Py-GC/MS. Proc Int Symp Wood Fiber Pulp Chem 15

Skals PB, Krabek A, Nielsen PH, Wenzel H (2008) Environmental assessment of enzyme assisted processing in pulp and paper industry. Int J Life Cycle Assess 13:124-132

Su Y, Wang EI, Farrell R, Ho C-I, Chang H-M (2004) Screening of fungi for removal of wood extractives. Proc Appita Annu Conf Exhibit 58:27-34

Sun RC, Sun XF (2001) Identification and quantitation of lipophilic extractives from wheat straw. Ind Crops Prod 14:51-64

Torres P, Datla A, Rajasekar VW, Zambre S, Ashar T, Yates M, Rojas-Cervantes ML, Calero-Rueda O, Barba V, Martínez MJ, Ballesteros A, Plou FJ (2008) Characterization and application of a sterol esterase 
immobilized on polyacrylate epoxy-activated carriers (Dilbeads (TM)). Catal Commun 9:539-545

Valls C, Molina S, Vidal T, del Río JC, Colom J, Martínez AT, Gutiérrez A, Roncero MB (2009) Influence of operation conditions on laccase-mediator removal of sterols from eucalypt pulp. Process Biochem Online. doi:10.1016/j. procbio.2009.05.002

van Beek TA, Kuster B, Claassen FW, Tienvieri T, Bertaud F, Lenon G, Petit-Conil M, Sierra-Alvarez R (2007) Fungal bio-treatment of spruce wood with Trametes versicolor for pitch control: Influence on extractive contents, pulping process parameters, paper quality and effluent toxicity. Bioresour Technol 98:302-311

Widsten P, Kandelbauer A (2008) Laccase application in the forest processing industries: a review. Enzyme Microb Technol 42:293-307

$\mathrm{Xu}$ F (2005) Applications of oxidoreductases: recent progress. Indust Biotechnol 1:38-50
Zhang X, Stebbing DW, Saddler JN, Beatson RP, Kruus K (2000) Enzyme treatments of the dissolved and colloidal substances present in mill white water and the effects on the resulting paper properties. J Wood Chem Technol 20:321-335

Zhang X, Eigendorf G, Stebbing DW, Mansfield SD, Saddler JN (2002) Degradation of trilinolein by laccase enzymes. Arch Biochem Biophys 405:44-54

Zhang X, Renaud S, Paice M (2005) The potential of laccase to remove extractives present in pulp and white water from TMP newsprint mills. J Pulp Paper Sci 31:175-180

Zhang X, Nguyen D, Paice MG, Tsang A, Renaud S (2007) Degradation of wood extractives in thermo-mechanical pulp by soybean lipoxygenase. Enzyme Microb Technol 40:866-873

Zimmerman WC, Blanchette RA, Burnes TA, Farrell RL (1995) Melanin and perithecial development in Ophiostoma piliferum. Mycologia 87:857-863 